\title{
VULNERABILIDADE TERRITORIAL E IMPLICAÇÕES SÓCIO-ESPACIAIS DA EXPANSÃO DO COMPLEXO SOJA NO MATO GROSSO DO SUL ${ }^{1}$
}

\author{
Ana Carolina Torelli Marquezini Faccin ${ }^{2}$ \\ Ricardo Abid Castillo ${ }^{3}$
}

Resumo: No presente artigo abordamos a situação de grande especialização produtiva no estado de Mato Grosso do Sul que compreende, em seu território, regiões profundamente ligadas à sojicultura. Com foco nessa atividade agrícola moderna, ressaltamos aspectos que consideramos fatores de vulnerabilidade territorial. A produção agrícola sul-mato-grossense é pouco diversificada e quase que totalmente voltada à exportação; assim, compreendemos que tal situação gera implicações nos âmbitos econômico, social e ambiental do estado. Pontuamos alguns aspectos relevantes e entendemos que um planejamento ordenado pela esfera pública poderia integrar diversos usos, trazendo também benefícios para a população sul-mato-grossense, cuja totalidade compreende diversas etnias indígenas, violentamente oprimidas e dizimadas, com sua cultura tendo cada vez menos espaço em uma economia baseada quase que totalmente no agronegócio.

Palavras-chave: Território; Mato Grosso do Sul; Soja; Especialização produtiva; Vulnerabilidade territorial.

\section{TERRITORIAL VULNERABILITY AND SOCIO-SPATIAL IMPLICATIONS OF SOYBEAN COMPLEX EXPANSION IN MATO GROSSO DO SUL}

Abstract: In this article we discuss the situation of significant productive specialization in the state of Mato Grosso do Sul, which includes regions deeply linked to soybean production. Focusing on this modern agricultural activity, we highlight aspects that we consider to be territorial vulnerability factors. South-Mato Grosso's agricultural production is little diversified and almost totally export-oriented; thus, we understand that this situation generates implications in the economic, social and environmental scope of the state. We point out some relevant aspects and understand that planning ordered by the public sphere could integrate several uses, also bringing benefits to the population of South Mato Grosso that includes several indigenous ethnic groups which have been violently oppressed and decimated, with their culture having less space over time in an economy based almost entirely on agribusiness.

Keywords: Territory; Mato Grosso do Sul; Soybean; Productive specialization; Territorial vulnerability.

\footnotetext{
${ }^{1}$ Pesquisa desenvolvida com apoio da CAPES e CAPES COFECUB.

${ }^{2}$ Doutora em Geografia pela Universidade Federal da Grande Dourados (UFGD). E-mail: caroltorelli.faccin@gmail.com

${ }^{3}$ Professor Doutor do Instituto de Geociências da Universidade Estadual de Campinas (UNICAMP). E-mail: castillo@ige.unicamp.br

Estudos Geográficos, Rio Claro, 15(1): 133-156, jan./jun. 2017 (ISSN 1678-698X)

http://www.periodicos.rc.biblioteca.unesp.br/index.php/estgeo
} 


\section{INTRODUÇÃO}

O estado de Mato Grosso do Sul tem se destacado, nos últimos anos, pela expressiva produção de soja, com grande destaque para a região de Dourados, localizada na porção centro-sul do estado (figura 1). Sua matriz exportadora (quadro 1) nos revela que os produtos do complexo-soja (soja triturada, farelo e óleo) ocupam a primeira posição entre os produtos exportados (a soma equivale a $28,9 \%$ ), seguido de perto pela parte que cabe à celulose $(23 \%)$, açúcar bruto de cana $(11 \%)$, carne bovina congelada (10\%) e milho em grãos $(7,6 \%)$.

Figura 1. Mato Grosso do Sul. Localização das lavouras de soja, cana-de-açúcar e eucalipto, 2016.

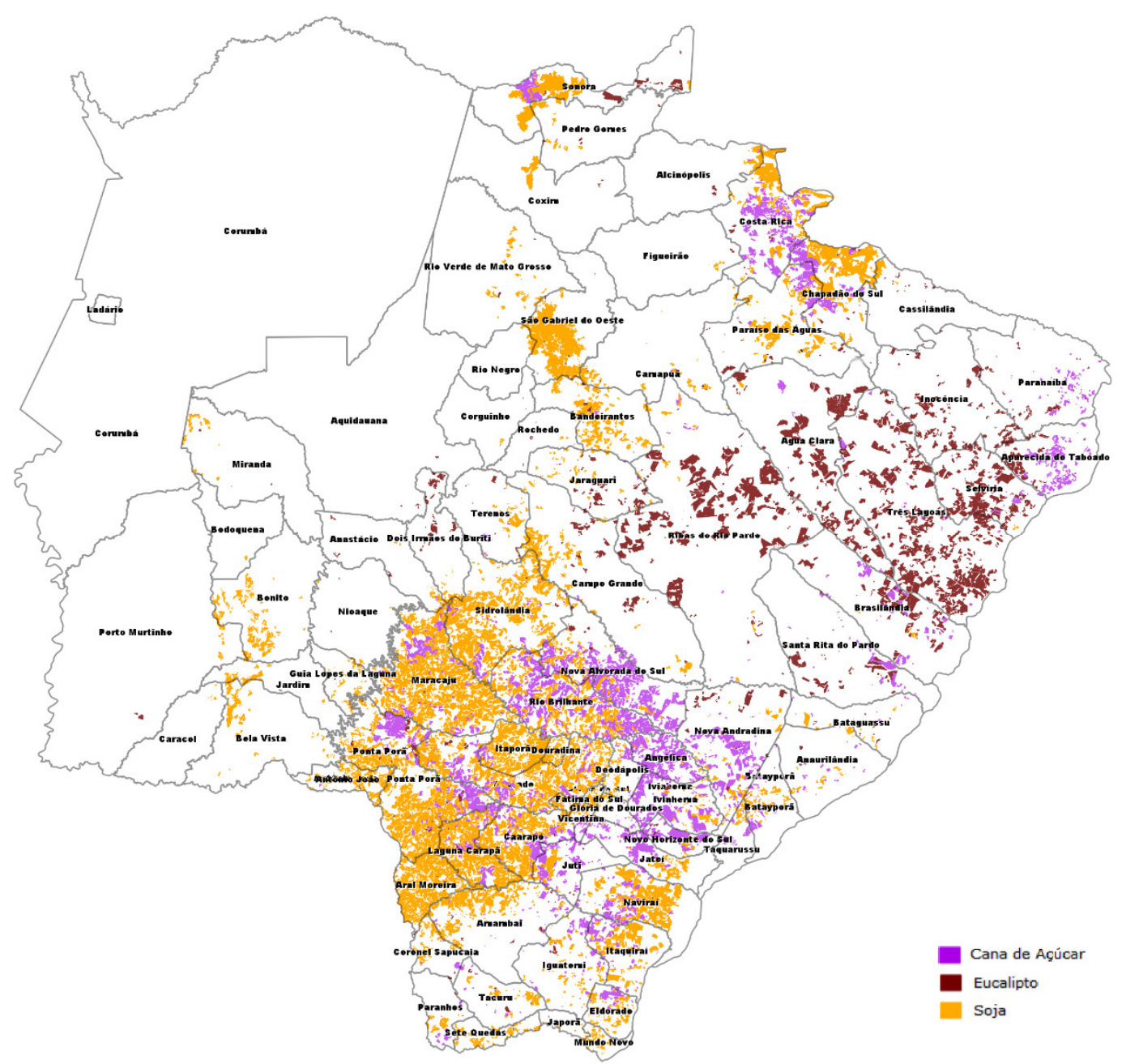

Fonte: SIGA MS (2017). Organizado pela autora.

A matriz produtiva de Mato Grosso do Sul é, de certa maneira, uma reprodução mais simplificada da visão geral dos produtos exportados pelo País e sugere um fato marcante: a soja, a pecuária, a cana-de-açúcar e a silvicultura são as atividades mestras da economia sul-mato-grossense, sendo que qualquer atividade de destaque (por exemplo, setor de indústria e, parcialmente, o de serviços) se 
desdobra dos produtos primários, ou seja, existe em função da manutenção dos circuitos espaciais criados para a efetivação dessas poucas atividades principais ${ }^{4}$.

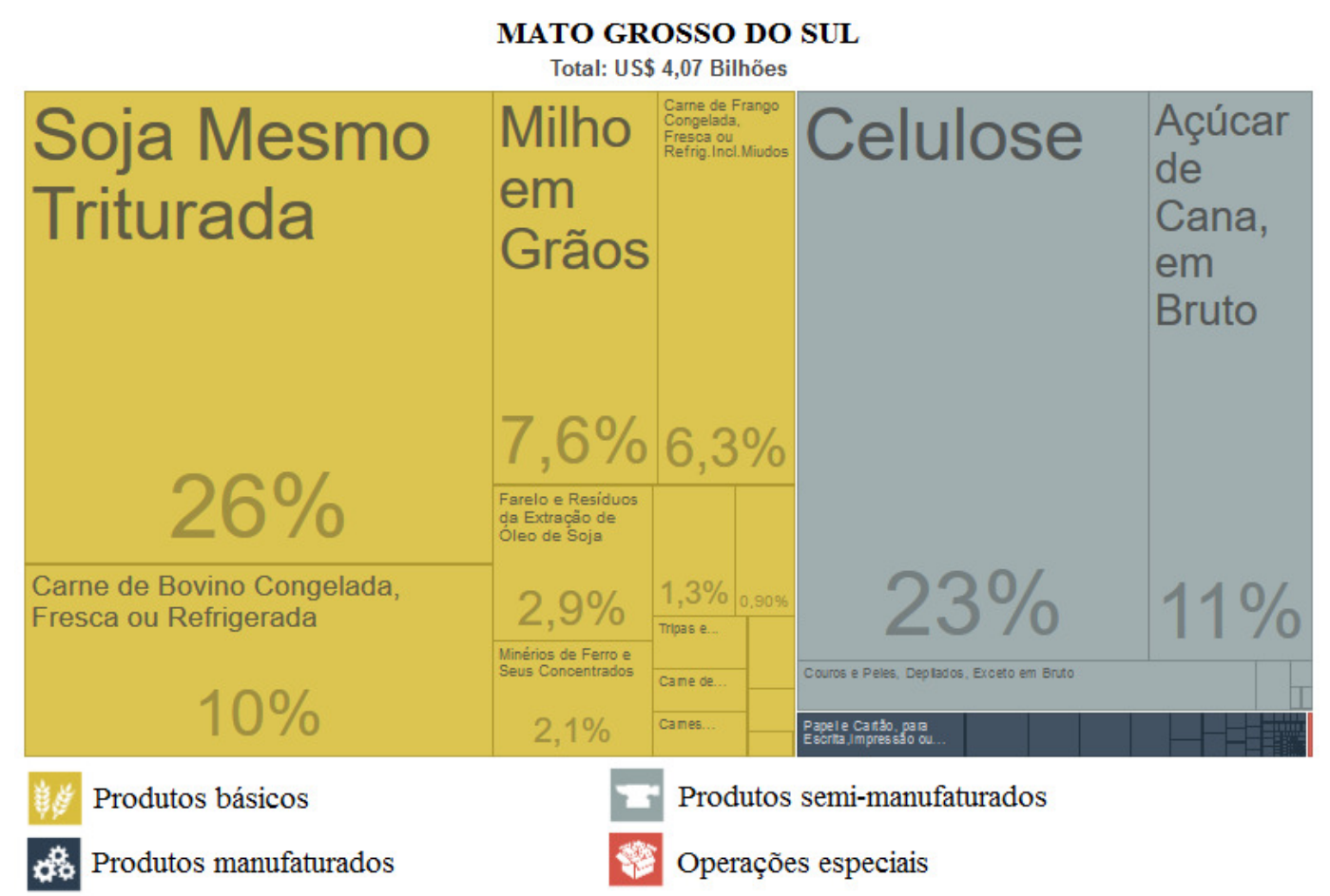

Quadro 1. Mato Grosso do Sul. Visão geral dos produtos exportados, 2016.

Fonte: Reprodução Comex vis/MDIC (2017).

Historicamente, a estrutura fundiária do estado de Mato Grosso do Sul sempre foi caracterizada pela presença de grandes propriedades rurais, o que é um fator importante para o sucesso da produção de monoculturas em larga escala. Pouco mudou no estado durante a transição de uma economia agropastoril para uma economia baseada na agroindústria, nas últimas décadas: grandes porções de terras nas mãos de poucos geram uma concentração de riqueza e domínio dos meios de produção; consequentemente, a concentração fundiária é evidente no território sul-mato-grossense, sendo que tal situação é um fato recorrente em todas as regiões do estado, notadamente na região pantaneira, porção noroeste do estado, tradicionalmente envolvida com atividades de extração mineral e pecuária.

Com foco na sojicultura, um de nossos objetivos com este artigo é apontar fatores que expressem a vulnerabilidade que regiões agrícolas possam apresentar por estarem tão fortemente ligadas ao mercado internacional. A vulnerabilidade das cidades do agronegócio (ELIAS, 2007) se dá em razão de acontecimentos externos, cujo controle ultrapassa a escala do lugar e da região. Ainda que as cidades sulmato-grossenses fortemente envolvidas com a soja não tenham tanto destaque como outras cidades intimamente ligadas à sojicultura (como Sorriso-MT e Rio Verde - GO), entre outras), acreditamos que, no momento presente, essas cidades

\footnotetext{
${ }^{4}$ Segundo a SEPAF/MS (Secretaria de Produção e Agricultura Familiar do Governo do Estado de Mato Grosso do Sul), o estado possui 30 milhões de hectares, sendo esses divididos em: a) 11 milhões vegetação nativa, b) 4 milhões grãos, c) 1 milhão 200 mil cana e d) 900 mil para silvicultura. As outras culturas são irrisórias, pois tudo deu espaço para as culturas de exportação. Entrevista realizada durante trabalho de campo em 25 e 26 de abril de 2016.
}

Estudos Geográficos, Rio Claro, 15(1): 133-156, jan./jun. 2017 (ISSN 1678-698X)

http://www.periodicos.rc.biblioteca.unesp.br/index.php/estgeo 
(particularmente Dourados, Maracaju e Ponta Porã, na região centro-sul do estado) são extremamente funcionais ao agronegócio e que podem, futuramente, apresentar grande vulnerabilidade territorial.

Para atestar de maneira concreta a evolução e os efeitos da cultura da soja em Mato Grosso do Sul nos âmbitos econômico, ambiental e social, temos que compreender sua dinâmica produtiva e fortalecer nosso entendimento sobre a especialização regional produtiva crescente no estado; assim, inicialmente, voltamos nossa atenção aos dados espacializados acerca da evolução da área plantada de soja (em hectares) no estado (figura 2), em intervalos de cinco anos (1990, 1995, 2000, 2005, 2010 e 2015).

Figura 2. Mato Grosso do Sul. Evolução da área plantada de soja: 1990, 1995, 2000, 2005, 2010 e 2015.

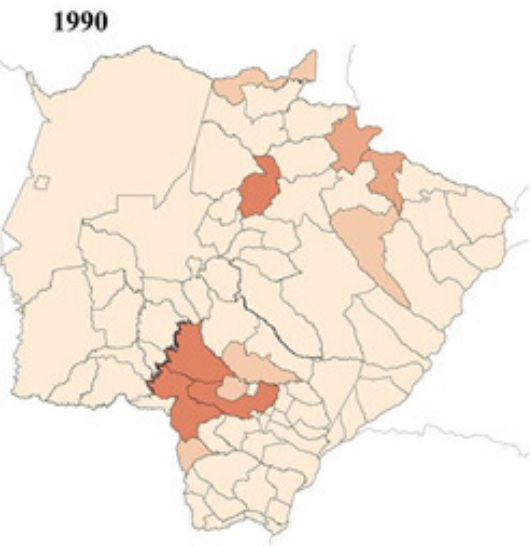

2005

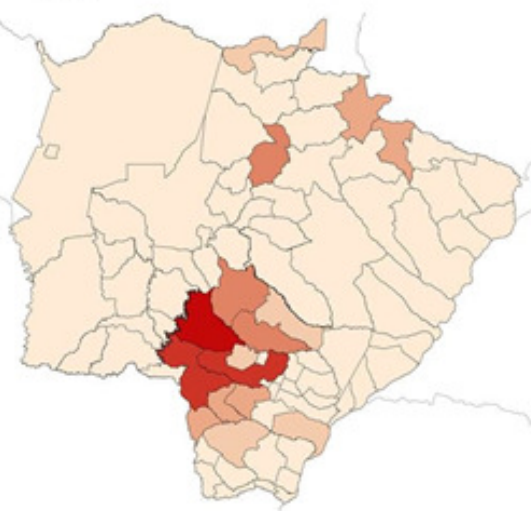

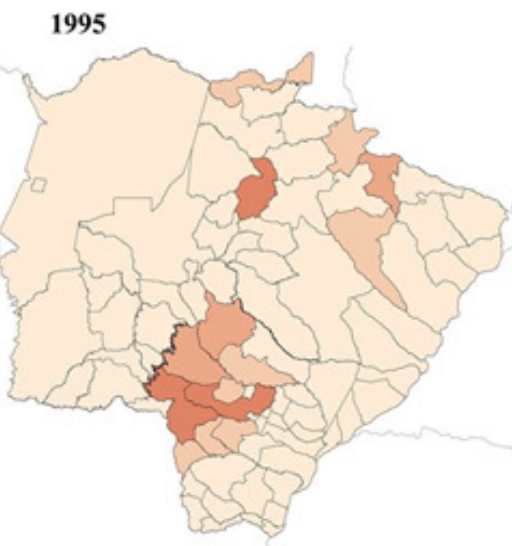

2010

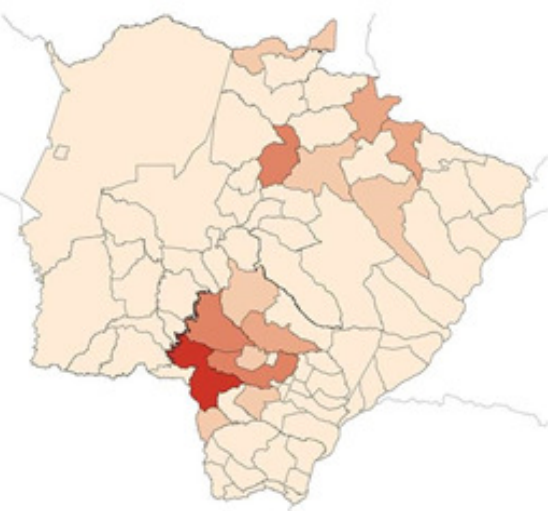

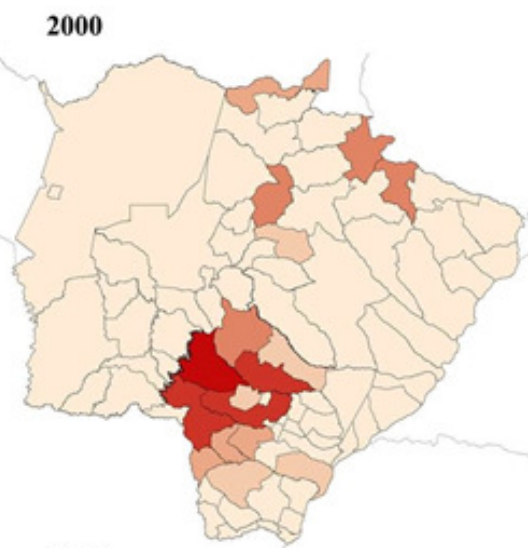

2015

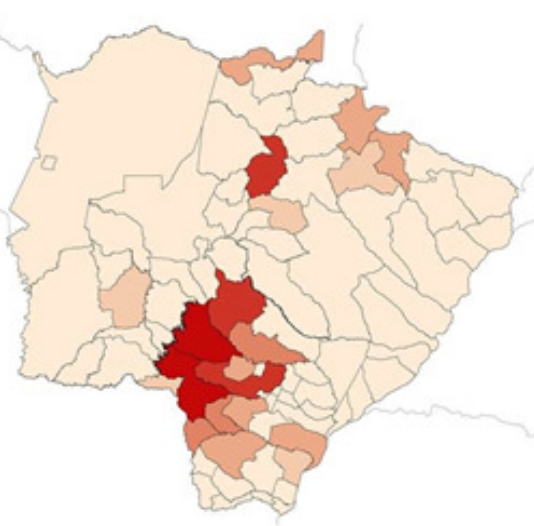

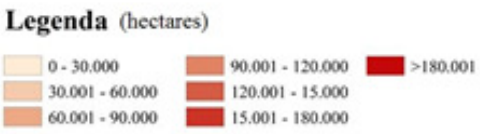

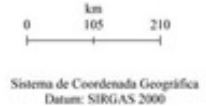

Fonte: Produção agrícola municipal, IBGE (2016). Organizado pela autora

Levando-se em conta o intervalo apresentado, podemos observar que, a partir do ano 2000, há um acentuado aumento da área plantada de soja em Mato Grosso do Sul. Há uma leve queda no ano 2010, talvez em decorrência da crise financeira mundial ocorrida em 2007-2008, mas podemos notar novamente um crescimento no ano 2015. É possível determinar que a expansão da área plantada se dá com 
poucos obstáculos, de maneira predatória sobre a vegetação nativa e pastagens, assim com intensificação a partir do ano de 2005.

Inferimos que, pelo consumo, a dinâmica produtiva sul-mato-grossense é quase que totalmente determinada por vetores externos e que a entrada da China na Organização Mundial do Comércio (OMC), a partir do ano 2001, reorganizou o espaço dos países periféricos com matriz exportadora baseada em produtos agrícolas, como o Brasil. Em Mato Grosso do Sul, o aumento da produção de soja é bastante perceptível nos dados, principalmente a partir do ano 2005; destaca-se a região de Dourados, especialmente os municípios de Maracaju, Dourados e Ponta Porã e, mais ao norte, o município de São Gabriel d'Oeste.

Assim, levando-se em conta o protagonismo da sojicultura no estado, apresentamos algumas considerações acerca de algumas implicações econômicas, sociais e ambientais ocasionadas pela expansão da soja no Mato Grosso do Sul.

\section{IMPLICAÇÕES ECONÔMICAS DA EXPANSÃO DA SOJA EM MATO GROSSO DO SUL}

Compreendemos que a economia dos municípios altamente funcionais ao agronegócio gira quase que completamente em torno da especialização produtiva em um ou poucos produtos. No caso da soja, podemos observar, com base na evolução da área plantada do grão (figura 2), que alguns municípios se mostram mais relacionados com a sojicultura do que com outras culturas, sendo que tal fato pode gerar situações de vulnerabilidade econômica nos próximos anos.

Uma situação emblemática é a do emprego rural em relação ao cultivo de soja. Por ser altamente tecnificada, desde o plantio até a colheita, a lavoura de soja demanda muito pouca mão-de-obra ${ }^{5}$. Assim, podemos afirmar que a cultura da soja, assim como outras lavouras modernizadas, não permite a fixação da maior parte da população rural no campo, além de represar grande parte das terras em função de suas atividades. Tal fato é uma constante em todo o País; as culturas com maior importância econômica são as que menos utilizam força de trabalho em circuitos produtivos (gráfico 1).

Gráfico 1. Distribuição de mão de obra nas principais culturas agrícolas no Brasil, 2014.

\section{EM MILHARES}
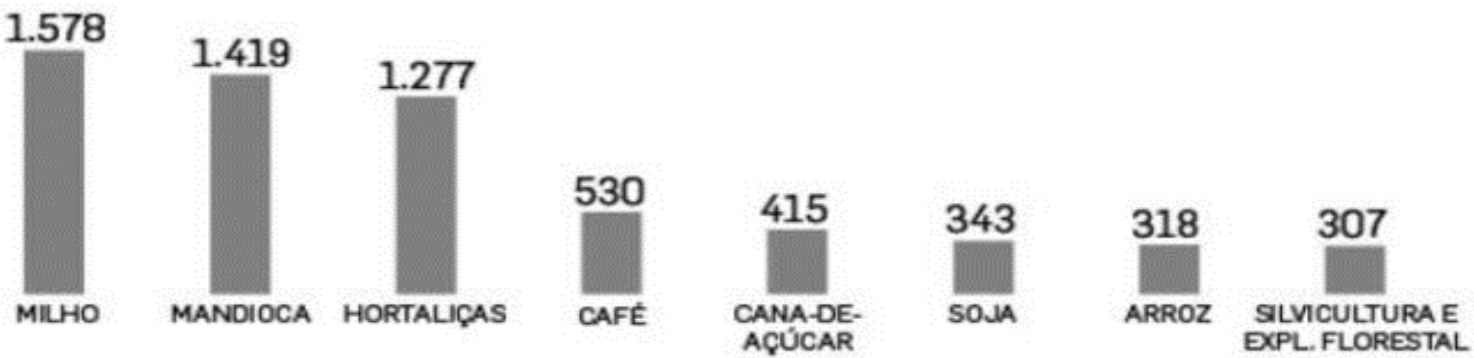

Fonte: CNA/PNAD-IBGE (2016).

\footnotetext{
${ }^{5}$ Apenas duas pessoas (um motorista para a colhedora e um motorista para o caminhão que leva os grãos até o silo) bastam para colher cerca de 60 hectares por dia em uma lavoura de soja/milho. O salário médio fica em torno dos $R \$ 3.000,00$ reais mensais. Informações levantadas durante entrevistas realizadas no mês de maio de 2013, em Dourados, durante colheita do milho "safrinha".

Estudos Geográficos, Rio Claro, 15(1): 133-156, jan./jun. 2017 (ISSN 1678—698X)

http://www.periodicos.rc.biblioteca.unesp.br/index.php/estgeo
} 
Com auxílio do gráfico 1 podemos observar que a elevada quantidade de trabalhadores no cultivo do milho deve-se ao fato de que grande parte dessa atividade é praticada pela agricultura familiar e é predominantemente trabalhointensiva; por outro lado, o milho safrinha produzido nas grandes propriedades, mesmo não recebendo os mesmos cuidados, investimentos e tratos culturais aplicados na cultura principal (soja), é uma atividade muito mais tecnologiaintensiva ${ }^{6}$.

Diante desse quadro, podemos supor que o processo produtivo agrícola moderno afeta negativamente os níveis de emprego da população nos municípios voltados ao agronegócio globalizado (ELIAS, 2007). Isso nos leva a propor a hipótese de que, no afã de atender a demanda mundial por commodities, o estado de Mato Grosso do Sul vem perdendo espaço para atividades diversificadas no campo, pautadas em circuitos curtos de comercialização. A agricultura intensiva, tão bem representada pelo cultivo da soja, mobiliza grandes extensões de terras e não mostra impacto positivo na criação de empregos formais, como podemos observar no gráfico 2.

Desse modo, de acordo com Mattei (2015),

(...) observa-se que em todo o país ocorreu uma substituição crescente das lavouras tradicionais com uso intensivo de trabalho por culturas agrícolas modernas e com baixo uso de mão de obra, além da expressiva incorporação das inovações tecnológicas em praticamente todas as etapas do processo produtivo, sobretudo naquelas culturas que ocupavam enormes quantidades de trabalhadores, como são os casos da cana-de-açúcar, do algodão, do café etc. (MATTEI, 2015, p. 37).

Gráfico 2. Mato Grosso do Sul. Número de empregos formais em dezembro de 2015.

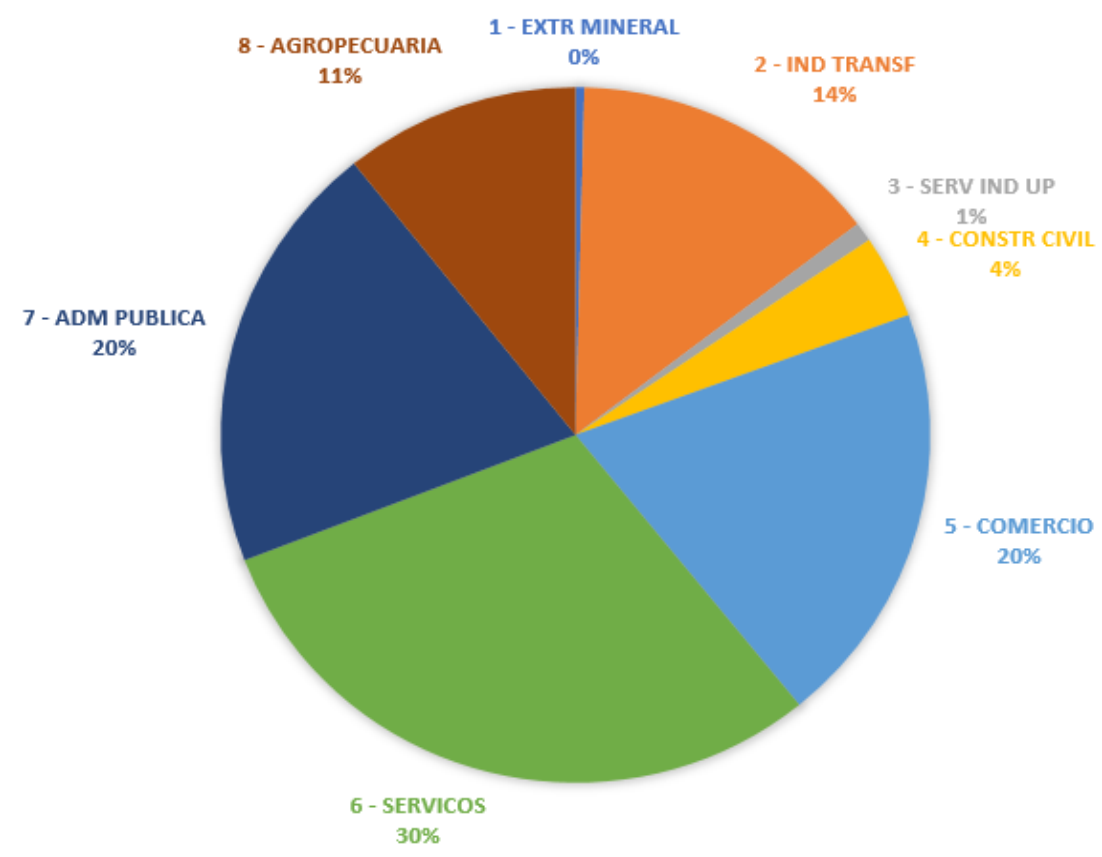

Fonte: RAIS/ ISPER (2017). Organizado pela autora.

\footnotetext{
${ }^{6}$ A significativa elevação da quantidade e do rendimento médio do milho como cultura de inverno nas grandes fazendas em áreas do Cerrado nos últimos anos, sugere que essa cultura vem recebendo mais atenção e investimentos por parte dos produtores.

Estudos Geográficos, Rio Claro, 15(1): 133-156, jan./jun. 2017 (ISSN 1678-698X)

http://www.periodicos.rc.biblioteca.unesp.br/index.php/estgeo
} 
Resguardadas as devidas proporções, o estado de Mato Grosso do Sul, por ter uma participação maior das atividades agropecuárias, apresenta uma média de emprego nessas atividades maior se comparado à média nacional (face aos empregos gerados pelo setor agropecuário, extração, caça e pesca). Porém, a participação do setor agropecuário ainda é bastante inferior no estado, assim como no País, em relação à alta empregabilidade dos setores envolvidos com indústria de transformação, comércio, administração pública e serviços.

Gonçalves (2011), ponderando sobre o possível momento de reprimarização atual da pauta exportadora brasileira, observa que

(...) ocupar cerrados com megalavouras de mecanização intensiva reduzindo a ocupação no meio rural cada vez mais será considerado contraproducente, pois segundo a Pesquisa Nacional por Amostra de Domicílio (PNAD) do Instituto Brasileiro de Geografia e Estatística (IBGE) a População Economicamente Ativa (PEA) no meio rural recuou em 3,9 milhões de pessoas no período 1992-2009. E mais, nesse espaço acumula- -se elevada proporção da dívida rural cuja solução vem sendo postergada enquanto que a expansão das lavouras amplia a dependência da importação de fertilizantes. Em síntese, a Reprimarização atende ao anseio de curto prazo para redução dos constrangimentos externos da economia brasileira, mas se mostra incompatível com o desenvolvimento brasileiro de longo prazo, que seja incorporador de massas assalariadas em empregos de qualidade superior e sustentável na ótica dos recursos naturais escassos (GONÇALVES, 2011, p. 7).

Basear a economia estadual no setor primário é fator de vulnerabilidade territorial, entre outras razões, pela impossibilidade de controlar algumas variáveis internas, como excepcionalidades climáticas que podem causar grandes prejuízos aos agricultores, às empresas de beneficiamento e processadores de matéria-prima, às empresas de armazenamento e transporte etc. e, evidentemente, à arrecadação estadual, ou externas, como queda dos preços das commodities nas bolsas de mercadorias, por excesso de estoque, pelo aumento da produção de países concorrentes, dentre outros, com reflexos particularmente importantes nas economias locais, na vida econômica dos municípios sul-mato-grossenses.

\section{IMPLICAÇÕES SOCIAIS DA EXPANSÃO DA SOJA EM MATO GROSSO DO SUL}

No que se refere às implicações sociais decorrentes da expansão da soja em Mato Grosso do Sul, chama muito a nossa atenção a questão dos arrendamentos praticados nas regiões sojícolas sul-mato-grossenses (também praticados em razão de outros cultivos, como o da cana-de-açúcar). A prática do arrendamento tornou-se comum após as lavouras de soja e cana-de-açúcar se expandirem em diversos pontos de Mato Grosso do Sul, particularmente na região centro-sul. O contrato feito entre produtor de soja ou a unidade sucroenergética e o proprietário da terra preveem a descaracterização quase que completa das áreas em função da implantação das lavouras, gerando um ambiente hostil a outras atividades, inclusive de pequenos produtores rurais, que se encontram sem suporte para criar outros circuitos de produção que não envolvam suas propriedades arrendadas.

Estudos Geográficos, Rio Claro, 15(1): 133-156, jan./jun. 2017 (ISSN 1678—698X)

http://www.periodicos.rc.biblioteca.unesp.br/index.php/estgeo 
Petrini (2017), discutindo o arrendamento na microrregião de Ceres (Goiás) voltada à cana-de-açúcar, argumenta que o pequeno produtor rural assume uma postura passiva face à sua propriedade, o que se configuraria em uma relação assimétrica de poder na prática do arrendamento. A autora conclui que a grande produção voltada à exportação de produtos primários é quase que incompatível com a agricultura familiar, situação que facilmente podemos observar em municípios dedicados à produção de soja em Mato Grosso do Sul.

O assentamento Itamarati (localizado no município de Ponta Porã) é um caso emblemático, arriscamos determinar. Os assentados têm pouquíssimo apoio para desenvolver atividades próprias; uma das saídas que se apresentam acaba sendo o arrendamento dos terrenos a valores irrisórios, que mal sustentam uma família (valores entre 7 a 21 sacas por hectare a cada safra, a um preço médio de 60 reais uma saca de soja ${ }^{7}$ ). Se os pequenos proprietários não arrendam, acabam com um terreno pequeno no meio de um "mar de soja" com estruturas precárias, pois tais assentamentos, especialmente o Itamarati, foram estabelecidos pelo INCRA (Instituto Nacional de Colonização e Reforma Agrária) "sem estudo, sem planejamento, sem manutenção, sem acompanhamento"8), criando uma situação social grave do ponto de vista da falta de ocupação e renda do trabalhador rural assentado.

Há outras experiências de assentamentos fora das regiões da soja em Mato Grosso do Sul. Os assentados na região da Serra da Bodoquena, por exemplo, praticam um cultivo mais diversificado (frutas exóticas, com certificação orgânica), sob contrato direto com países europeus, como a Alemanha. Nesses casos, a remuneração é razoável, mantém as famílias ocupadas e bem estruturadas no campo e com apoio técnico ${ }^{9}$, ainda que seja via demanda e consumo externos.

Em Mato Grosso do Sul nota-se a fraqueza, a pouca efetividade das lideranças dos pequenos agricultores e pequenos proprietários de terras, que deveriam representar as demandas desta classe social frente ao governo, sobretudo quando se constata que as demandas dos grandes produtores e empresas estão bem representadas e costumam ser atendidas, independente da cultura a que se dedicam. Para os pequenos, parece faltar uma capacidade de organização por conta própria, que pode ser reforçada pelo atual cenário de retração das políticas públicas para a agricultura familiar no estado.

O propósito do agricultor familiar é produzir para si e para o mercado, com capacidade de geração de renda (sendo este o objetivo primário a ser alcançado segundo diretrizes da FAO), escolhendo atividades possíveis em um ambiente voltado à grande produção, quase que inóspito para a pequena produção diversificada. Porém, em Mato Grosso do Sul, o perfil da "diversificação possível" leva à especialização das atividades produtivas, mesmo que em pequenas propriedades. Segundo a Secretaria de Produção e Agricultura Familiar/MS, não é opção para o Governo do Estado financiar empreendimentos fora do modelo atual; para esta, a opção mais viável para fixação do homem no campo seriam os aviários ou criação de suínos (à exemplo da cooperativa Aurora), com apoio do FCO (Fundo Constitucional de Financiamento do Centro-Oeste).

\footnotetext{
${ }^{7}$ Entrevista realizada com Alex Lima, morador do assentamento Itamarati, em dezembro de 2016.

8 Informações obtidas em entrevista com representante da SEPAF/MS (Secretaria de Produção e Agricultura Familiar do Governo do Estado de Mato Grosso do Sul). Entrevista realizada durante trabalho de campo em 25 e 26 de abril de 2016.

${ }_{9}$ Os assentados da região da Serra da Bodoquena são objeto de pesquisas variadas (com farto material iconográfico) sob orientação do professor doutor Edvaldo Moretti, docente do curso de Geografia da Faculdade de Ciências Humanas/UFGD.

Estudos Geográficos, Rio Claro, 15(1): 133-156, jan./jun. 2017 (ISSN 1678-698X)

http://www.periodicos.rc.biblioteca.unesp.br/index.php/estgeo
} 
Mato Grosso do Sul, de maneira geral, apresenta uma tendência produtiva centrífuga, extravertida e uma profunda questão agrária não resolvida, contrastante com a questão da grande produção agroindustrial moderna. Os conflitos por terra são pulsantes no estado, principalmente em áreas passíveis de demarcação de terras indígenas, com conflitos armados entre fazendeiros e lideranças indígenas em municípios como Caarapó e Antônio João, localizados na região de Dourados.

Podemos observar, com auxílio da figura 3, a localização precisa das lavouras de soja, projetos de assentamentos e terras indígenas para o ano de 2016. Os conflitos gerados por essa coexistência têm consequências no modo de vida das populações residentes nessas áreas. Cria-se uma dicotomia bastante clara, ainda que simplista: de um lado há a população indígena, vista como indolente e dependente do Estado para sobreviver e, de outro lado, uma fração, possivelmente majoritária, da população que é abertamente hostil a essa população indígena e às políticas e instituições, como a FUNAI (Fundação Nacional do İndio), que visem promover e garantir os direitos básicos dessas nações presentes no território brasileiro e em vários países sul-americanos.

Em cidades com grande população indígena, como Amambai e Dourados, ocorre uma convivência não-amigável da população com os indígenas (de diversas etnias e características culturais muito particulares, cabe ressaltar). A população indígena está presente no cotidiano, mas sua presença é quase que "invisível", termo que melhor explicita o quanto é indesejável o convívio com essas etnias.

Há uma representação geral desfavorável da imagem do indígena nas cidades sul-mato-grossenses. Tal população não seria digna de auxílio social e econômico, pois nada produziria e sua cultura não se ajustaria às exigências da chamada sociedade moderna. Um problema desconsiderado pela maioria da população é enfatizado pela FUNAl: as terras demarcadas e destinadas às populações indígenas sul-mato-grossenses não mais comportam seu contingente populacional, que tem apresentado crescimento exponencial com o passar dos anos $^{10}$.

Segundo entrevista com a representação técnica da FUNAl de Dourados, poderíamos fazer a seguinte aproximação, em 2013: se pegássemos a área total das aldeias Jaguapiru e Bororó (3.600 hectares $\left.{ }^{11}\right)$ e dividíssemos pelo número de famílias residentes, o resultado revelaria que cada família (com membros acima de 5 pessoas) teria à disposição apenas $300 \mathrm{~m}^{2}$ ou 0,03 hectares. Tal área é claramente insuficiente para qualquer tipo de produção agrícola (seja qual for seu porte) e também há de se levar em consideração o fato de que novas famílias se formam a cada ano e a pressão por terras aumenta.

Essa situação confinadora tende a se agravar cada vez mais visto que, no ano de 2015, viviam cerca de 16.000 indígenas nessas duas aldeias mencionadas (localizadas no município de Dourados, na divisa com o município de Itaporã). Junto a esse agravamento, é crescente a hostilidade de grande parte da população em relação aos indígenas, o que provoca uma espécie de alinhamento mental coletivo com lógicas mundiais de produtividade e competitividade das quais, além dos indígenas, trabalhadores rurais sem-terra, camponeses e lavradores simplesmente não fazem parte.

\footnotetext{
${ }^{10}$ Informações obtidas em entrevistas realizadas em maio de 2013 e agosto de 2015 na divisão técnica da Coordenação Regional de Dourados da FUNAI.

11 A chamada Reserva Indígena de Dourados foi demarcada em 1916, compreendendo 3.600 hectares. Atualmente 3.530 hectares estão em posse da população indígena; o restante (70 hectares) está em poder e uso irregular "nas mãos dos brancos", segundo a FUNAI.

Estudos Geográficos, Rio Claro, 15(1): 133-156, jan./jun. 2017 (ISSN 1678-698X)

http://www.periodicos.rc.biblioteca.unesp.br/index.php/estgeo
} 
Figura 3. Mato Grosso do Sul. Localização das lavouras de soja, projetos de

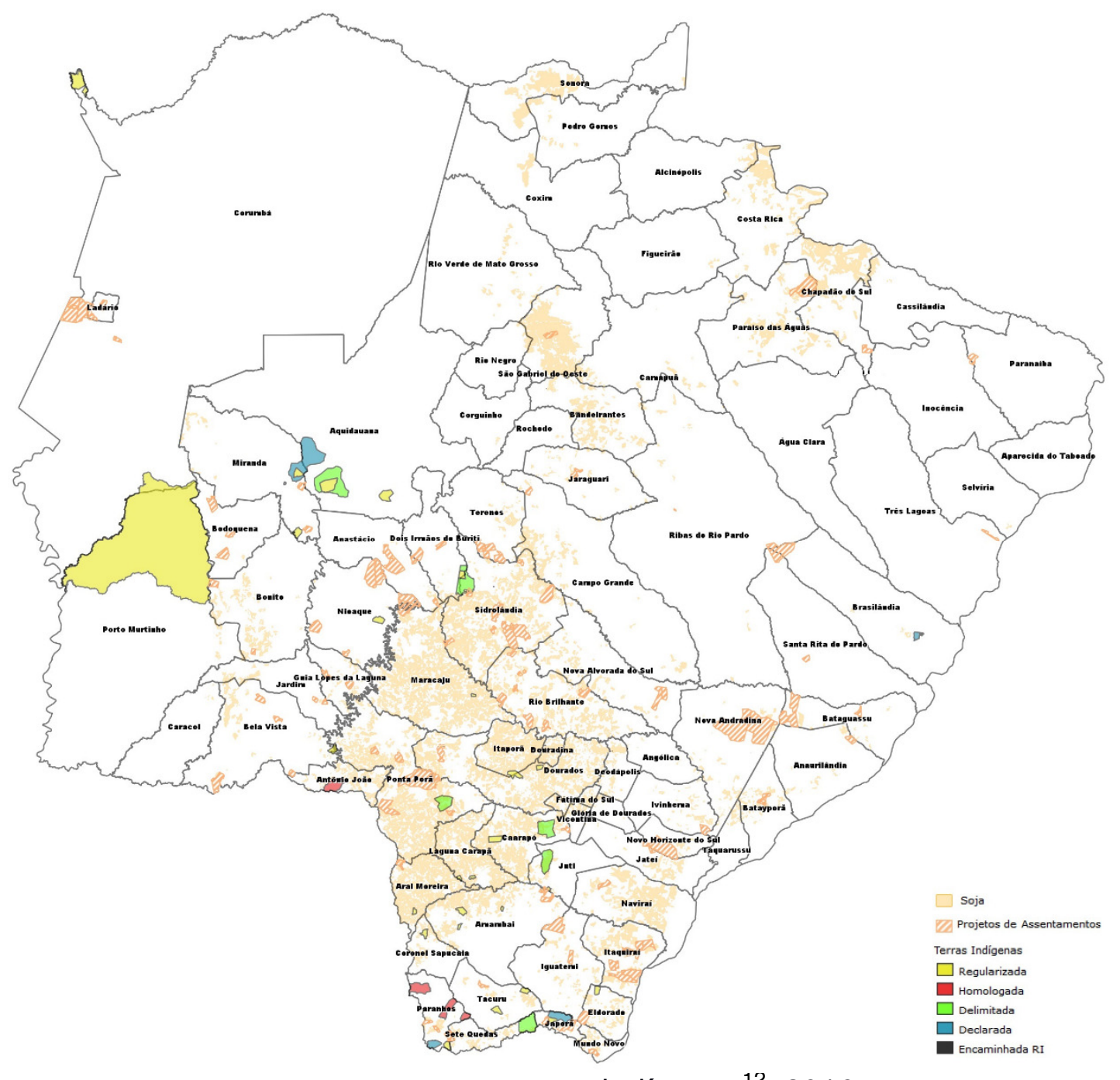

assentamentos e terras indígenas ${ }^{12}, 2016$.

Fonte: SIGA MS (2017). Organizado pela autora.

Nesse contexto, identificamos em Mato Grosso do Sul, particularmente nos municípios voltados à agropecuária com produção extravertida, uma situação que nos remete aos conceitos de tecnosfera e psicosfera (SANTOS, 1996).

Ao mesmo tempo em que se instala uma tecnosfera dependente da ciência e tecnologia, cria-se, paralelamente, e com as mesmas bases, uma psicosfera. A tecnosfera se adapta aos mandamentos da produção e do intercâmbio e, desse modo, frequentemente traduz interesses distantes; desde, porém, que se instala, substituindo o meio natural ou o meio técnico que a precedeu, constitui um dado local, aderindo ao lugar como uma prótese. A psicosfera, reino das ideias, crenças, paixões e lugar da produção de um sentido, também

\footnotetext{
${ }^{12}$ A figura, produzida com auxílio da base técnica e software do SIGA/MS, não permitiu a mudança de cores que representam a presença das lavouras de soja e dos projetos de assentamentos. Assim, os projetos de assentamentos são representados em uma cor ligeiramente parecida com a cor das lavouras de soja, porém apresenta hachuras para sua diferenciação.
}

Estudos Geográficos, Rio Claro, 15(1): 133-156, jan./jun. 2017 (ISSN 1678—698X)

http://www.periodicos.rc.biblioteca.unesp.br/index.php/estgeo 
faz parte desse meio ambiente, desse entorno de vida, fornecendo regras à racionalidade ou estimulando o imaginário. Ambas tecnosfera e psicosfera - são locais, mas constituem o produto de uma sociedade bem mais ampla que o lugar. Sua inspiração e suas leis têm dimensões mais amplas e mais complexas (SANTOS, 1996, p. 256).

Como bem definido por Pereira e Kahil, "o território modernizado pela agricultura científica ganha verdadeiro status de espaço 'modelo', signo do progresso e do crescimento econômico, realimentando a psicosfera legitimadora da atualização corporativa e hierárquica (SANTOS, 1996) " (PEREIRA \& KAHIL, 2010, p. 293).

Há, em resumo, uma certa expulsão ideológica de sistemas de crença e culturas que não estejam alinhados com a lógica corporativa do agronegócio (PEREIRA \& KAHIL, 2010). A maioria da população sul-mato-grossense não se beneficia das atividades realizadas pelas empresas (que concentram a maior parte das áreas e recursos), mas defendem essa ideologia como sendo a vencedora e promotora de resolução de problemas que atingem a massa de pessoas que vive nessas regiões. A essa situação classificamos, em nossa pesquisa, como sendo uma situação de "psicosfera do agronegócio", detalhada no quadro 2, a seguir.

Quadro 2. "Psicosfera do agronegócio" em Mato Grosso do Sul.

\begin{tabular}{|c|c|c|}
\hline \multicolumn{3}{|c|}{$\begin{array}{c}\text { PSICOSFERA DO AGRONEGÓCIO } \\
\text { Mato Grosso do Sul }\end{array}$} \\
\hline AGENTES & $\begin{array}{c}\text { População/nações tradicionais } \\
\text { (indígenas, quilombolas), } \\
\text { Trabalhadores sem-terra, } \\
\text { agricultores familiares. }\end{array}$ & $\begin{array}{c}\text { Agricultores modernos, "gaúchos", } \\
\text { "paulistas", comerciantes do setor } \\
\text { agro, tradings agrícolas }\end{array}$ \\
\hline $\begin{array}{c}\text { REPRESENTAÇÃO/ } \\
\text { IMAGINÁRIO SOCIAL }\end{array}$ & $\begin{array}{c}\text { Cultura atrasada, indolentes, } \\
\text { bárbaros, vetor de miséria e } \\
\text { violência; Imagem de fracasso. }\end{array}$ & $\begin{array}{c}\text { Produtor rural que "alimenta o } \\
\text { Brasil", "o Brasil que deu certo", } \\
\text { "celeiro do mundo", vetor de } \\
\text { desenvolvimento e civilidade; } \\
\text { Imagem de sucesso. }\end{array}$ \\
\hline MODO DE VIDA & $\begin{array}{c}\text { Agricultura familiar, pequena } \\
\text { produção voltada à subsistência, } \\
\text { diversificação produtiva, mercado } \\
\text { local }\end{array}$ & $\begin{array}{c}\text { Agricultura empresarial, lógica } \\
\text { corporativa, produção extravertida, } \\
\text { demanda internacional. }\end{array}$ \\
\hline $\begin{array}{c}\text { APOIO } \\
\text { POLÍTICO/IDEOLÓGICO } \\
\text { EXTERNO }\end{array}$ & $\begin{array}{c}\text { FUNAl, poucos representantes } \\
\text { políticos a favor de projetos de } \\
\text { demarcação de terras e reforma } \\
\text { agrária; Apoio popular restrito, em } \\
\text { geral, oriundo do ambiente } \\
\text { acadêmico. }\end{array}$ & $\begin{array}{c}\text { Bancada ruralista, apoio midiático } \\
\text { (campanhas e reportagens); Apoio } \\
\text { governamental/político e popular } \\
\text { quase irrestrito (adesivos em carros } \\
\text { e faixas*) }\end{array}$ \\
\hline
\end{tabular}

* Adesivos com os dizeres "Produção sim/Demarcação não" e "Eu alimento o Brasil" são comuns em veículos sul-matogrossenses (geralmente em caminhonetes de uso agrícola).

Fonte: Diversas fontes ${ }^{13}$. Organizado pela autora.

A psicosfera do agronegócio se materializa fortemente nas mídias local e nacional, propondo um modelo baseado em alta tecnologia e capital intensivos, com

\footnotetext{
${ }^{13}$ Diversas fontes de informação, tais como as entrevistas realizadas em trabalhos de campo durante todo o período desta pesquisa (2013 a 2017), reportagens de jornais locais, declarações cotidianas de cidadãos em vários municípios sul-mato-grossense, com destaque para Campo Grande, Dourados e Ponta Porã.

Estudos Geográficos, Rio Claro, 15(1): 133-156, jan./jun. 2017 (ISSN 1678—698X)

http://www.periodicos.rc.biblioteca.unesp.br/index.php/estgeo
} 
capacidade de gerar empregos e renda para poucos no lugar, uma vez que sua base é a produção de commodities para um circuito produtivo de alcance mundial.

\section{IMPLICAÇÕES AMBIENTAIS DA EXPANSÃO DA SOJA EM MATO GROSSO DO SUL}

Como bem pontuado por Albrecht e Missio (ALBRECHT \& MISSIO, 2013), é impossível dissociar o agronegócio brasileiro do cultivo de espécies transgênicas, especialmente no caso da soja e do milho. Ao longo da história, as espécies vegetais e animais sempre foram submetidas a seleções artificiais, cujos resultados chegaram nas variações de alimentos que estão em oferta atualmente. Essas seleções evoluíram para o nível molecular e o melhoramento genético se sofisticou possibilitando, por exemplo, que a soja se "tropicalizasse".

O melhoramento genético é muito proeminente em espécies de "relevância agronômica" (DESTRO\&MONTALVAN, 1999 apud MISSIO \& GRANGE, 2013), ou seja, espécies vegetais interessantes para o agronegócio mundial. A soja, na qualidade de flex-crop, é o melhor exemplo de como a transgenia pode ser aplicada a uma espécie, possibilitando seu cultivo em todo o globo e aumentando seu valor econômico, além de alcançar inúmeros resultados considerados benéficos no período atual (tabela 1).

Tabela 1. Principais objetivos do melhoramento genético de plantas.

\begin{tabular}{|c|c|c|}
\hline Objetivo & & Descrição \\
\hline Aumento na produtividade & & $\begin{array}{l}\text { De grãos, raízes, tubérculos, folhas, caules, frutos e troncos; } \\
\text { Teor de óleo de proteínas; } \\
\text { Teor ou qualidade de certos ingredientes ativos com plantas } \\
\text { medicinais e aromáticas; } \\
\text { De látex (seringueira) e fibras de madeira; } \\
\text { Eficiência fotossintética (todas as espécies); } \\
\text { Tolerância ao pisoteio (forrageiras); } \\
\text { Capacidade de recuperação da parte aérea após o corte } \\
\text { (forrageiras, chás, cana-de-açúcar, erva mate, etc.). }\end{array}$ \\
\hline Resistência a fatores abióticos & & $\begin{array}{l}\text { Tolerância à acidez e/ou presença de elementos tóxicos no } \\
\text { solo; } \\
\text { Tolerância ao déficit hídrico e ao aquecimento global; } \\
\text { Insensibilidade ao fotoperíodo; } \\
\text { Tolerância à salinidade do solo ou água; } \\
\text { Tolerância a baixas temperaturas. }\end{array}$ \\
\hline Aumento da qualidade & & $\begin{array}{l}\text { Qualidade nutricional dos alimentos; } \\
\text { Qualidade nutricional de forragens; } \\
\text { Qualidade da fibra (algodão); } \\
\text { Qualidade do óleo (soja, algodão, milho, mamona, girassol, } \\
\text { amendoim, pinhão, manso, etc.); } \\
\text { Redução de substâncias tóxicas; } \\
\text { Aumento da palatabilidade de grãos e frutos; } \\
\text { Obtenção de frutos sem sementes (citrus e melancia); } \\
\text { Aumento da qualidade aparente (flores e plantas } \\
\text { ornamentais). }\end{array}$ \\
\hline Resistência a fatores bióticos & & $\begin{array}{l}\text { Tolerância ou resistência a doenças; } \\
\text { Tolerância ou resistência a pragas; } \\
\text { Tolerância ou resistência a nematoides. }\end{array}$ \\
\hline $\begin{array}{l}\text { Colheita, processamento } \\
\text { comercialização }\end{array}$ & & $\begin{array}{l}\text { Alteração no hábito de consumo de crescimento, altura das } \\
\text { plantas, altura de espigas, altura de inserção da primeira } \\
\text { vagem; } \\
\text { Homogeneidade na maturação de sementes ou frutos; } \\
\text { Alteração no tamanho e formato de frutos; }\end{array}$ \\
\hline
\end{tabular}

Estudos Geográficos, Rio Claro, 15(1): 133-156, jan./jun. 2017 (ISSN 1678—698X)

http://www.periodicos.rc.biblioteca.unesp.br/index.php/estgeo 


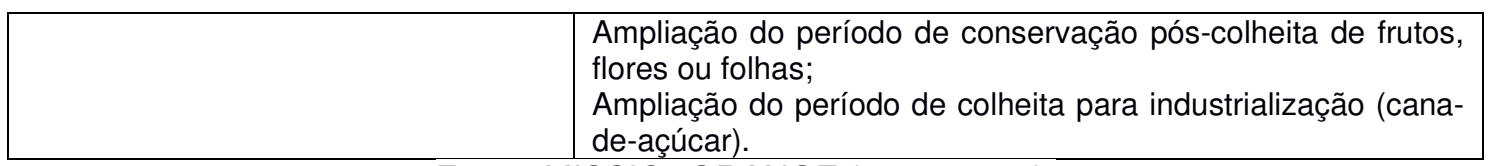

Fonte: MISSIO\&GRANGE (2013, p. 11).

Atualmente, a seleção artificial das melhores variedades (de soja, milho, entre outras espécies vegetais altamente rentáveis) foi somada às melhores e mais modernas técnicas agrícolas de adubação e cultivo, além do uso de máquinas extremamente especializadas para cada cultura, além de melhores condições de armazenamento, o que possibilitou enorme crescimento no rendimento das lavouras modernas, sem aumento significativo das áreas de cultivo (MISSIO \& GRANGE, 2013). Países com economia periférica, como Brasil e Argentina, alcançaram patamares de "primeiro mundo" na atividade agrícola, com aumento exponencial da produção, em especial da soja, utilizando mecanização intensiva e alta tecnologia, com aumento médio da produtividade em $50 \%$ nos últimos trinta anos (MISSIO \& GRANGE, 2013).

Longe de tentar sanar o problema da fome no mundo, o aumento da produtividade/rendimento das lavouras, em razão do advento da modificação genética, alavancou outra consequência: o aumento exponencial do uso de insumos químicos utilizados em conjunto com as espécies transgênicas. A princípio, essa equação não tem lógica: se as espécies vegetais são projetadas, em nível molecular para desenvolver tolerância a fatores bióticos (tabela 1), por que o uso de agrotóxicos ${ }^{14}$ e outros insumos químicos só aumentaram nos últimos anos, inclusive no Brasil, um dos maiores consumidores mundiais dessas substâncias?

A ideia de que os transgênicos demandariam menos agrotóxicos na prática não acontece. Pode usar menos de outros tipos, mas o herbicida é muitíssimo utilizado, inclusive aumentou o uso. De 2000 a 2010 aumentou mais de 155\% a quantidade de agrotóxicos por hectare no Brasil. Isso também vem na esteira desse aumento muito grande dos cultivos de soja, cana. Se formos falar por cultivo, a soja sozinha responde por quase metade de todo agrotóxico comercializado no Brasil. O milho em segundo lugar, cana em terceiro (BOMBARDI, 2016, p.1).

No gráfico 3 pode-se constatar o uso de agrotóxicos por cultura, no Brasil, para o ano de 2009.

\footnotetext{
${ }^{14}$ Usualmente, "agrotóxicos são definidos como quaisquer produtos de natureza biológica, física ou química com a finalidade de exterminar pragas ou doenças que atacam as culturas agrícolas" (SINDIVEG, 2016, p. 2).

Estudos Geográficos, Rio Claro, 15(1): 133-156, jan./jun. 2017 (ISSN 1678-698X)

http://www.periodicos.rc.biblioteca.unesp.br/index.php/estgeo
} 
Gráfico 3. Brasil. Uso de agrotóxicos por cultura (valores referentes às vendas de produtos), 2009.

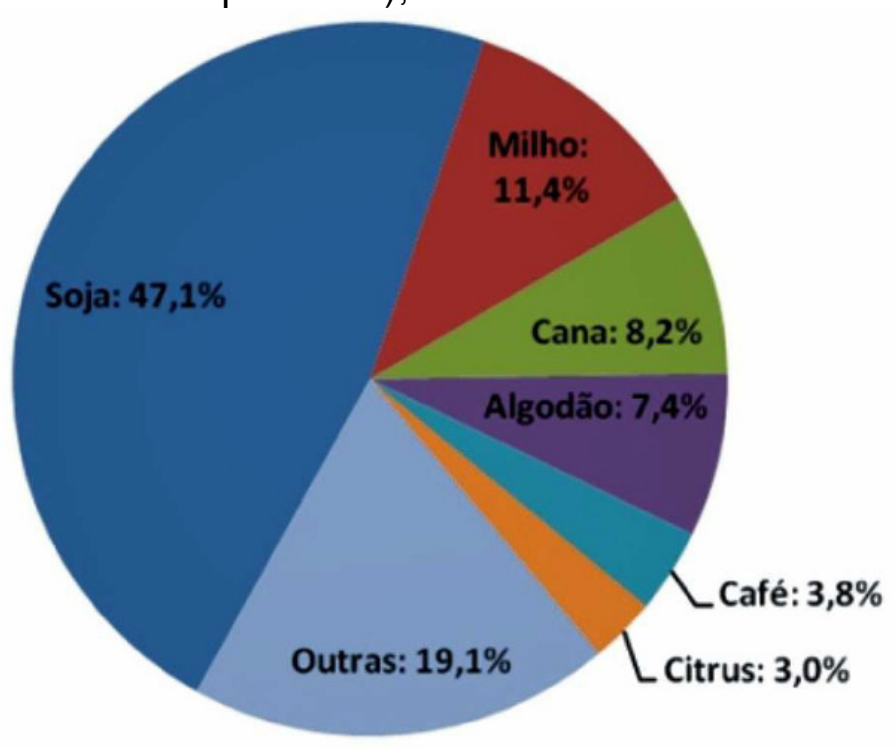

FONTE: Adaptado de: BPASIL. Ministério do Meio Ambiente, Instituto Brasileiro do Meio Ambiente e dos Recursos Naturais Renovàe is. Produtos agotóxicos e afins comercializados em $2009 \mathrm{no}$ Brasil: uma abordagem ambiental. Rafae la Maciel Rebelo... [et al] - Brasilia: lbama. 2010.

Fonte: BOMBARDI (2016).

Assim como o uso por cultura tem aumentado nos últimos anos, também se tem observado o aumento da comercialização e consumo de agrotóxicos no Brasil (gráfico 4) e a mesma dinâmica de consumo, em Mato Grosso do Sul (gráfico 5).

Gráfico 4. Histórico da comercialização e consumo de agrotóxicos e afins no Brasil, 2000 a 2014.

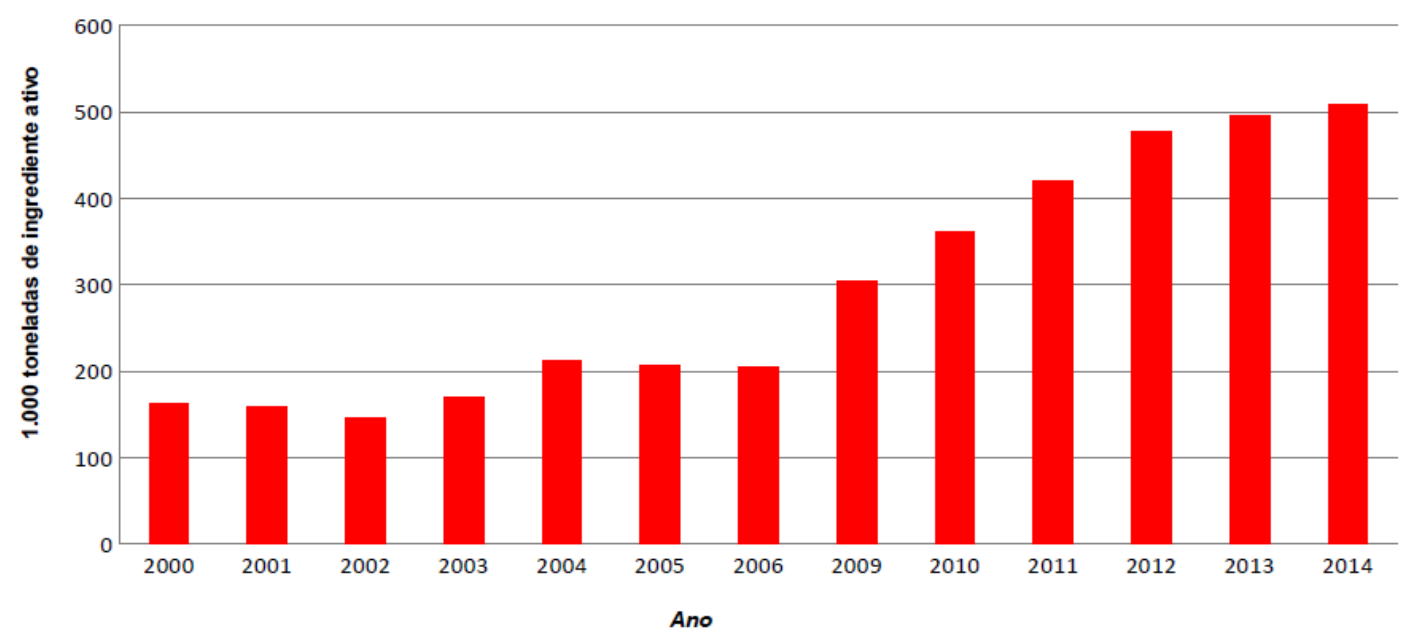

Fonte: IBAMA, 2016.

Estudos Geográficos, Rio Claro, 15(1): 133-156, jan./jun. 2017 (ISSN 1678—698X)

http://www.periodicos.rc.biblioteca.unesp.br/index.php/estgeo 
Gráfico 5. Mato Grosso do Sul. Consumo de agrotóxicos, por tipo, 2009 a 2015.

CONSUMO DE AGROTÓXICOS EM MATO GROSSO DO SUL, 2009-2015

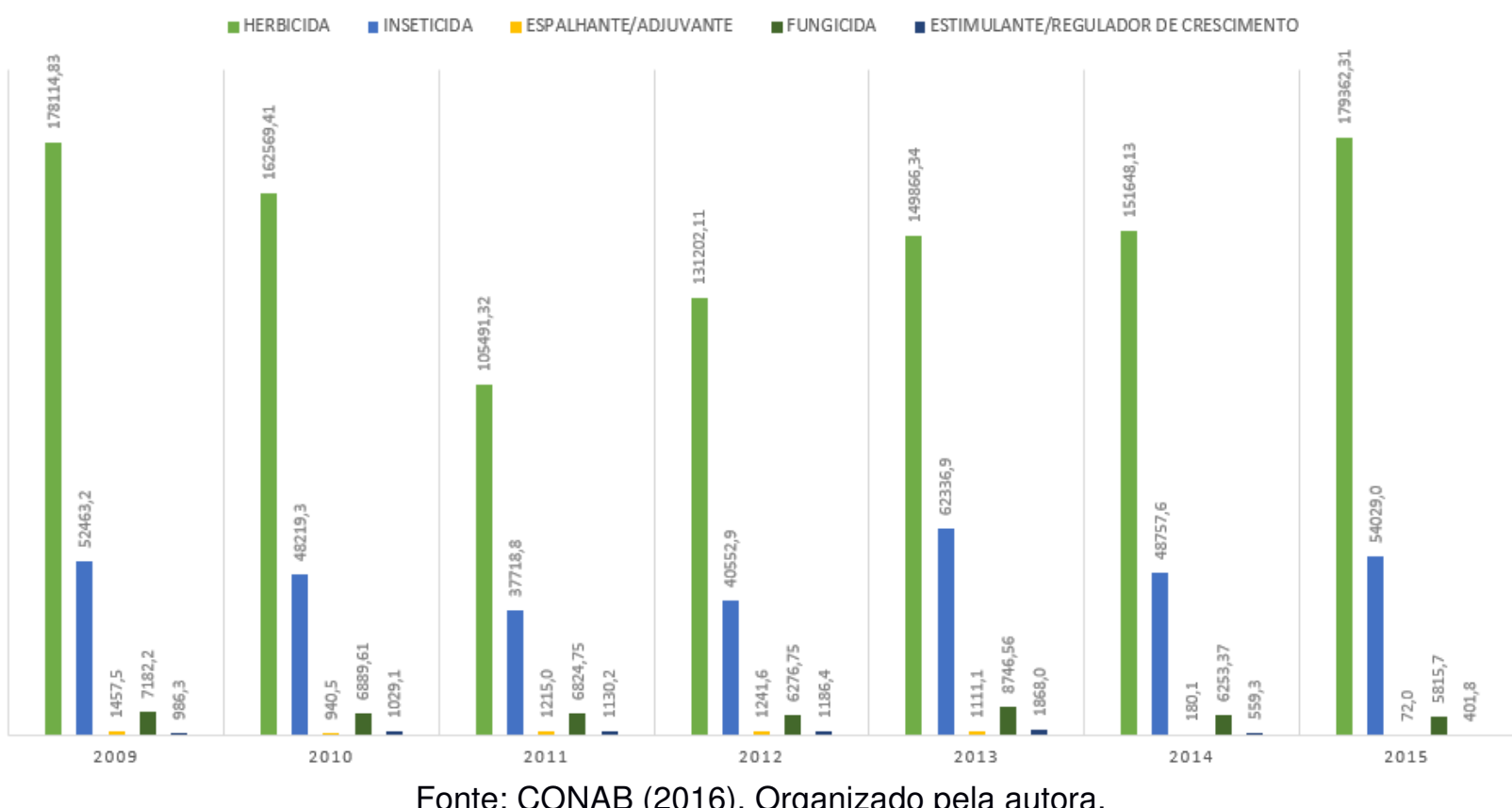

Fonte: CONAB (2016). Organizado pela autora.

Essa relação contraditória entre transgênicos e agrotóxicos e, consequentemente, o aumento do seu consumo nas regiões produtoras, são promovidos pela busca constante por maior competitividade nas atividades agrícolas. Tal objetivo compreende, entre outros fatores, alcançar cada vez mais uma maior quantidade produzida por hectare nas lavouras de soja (ou seja, maior rendimento). O gráfico 6 exemplifica a comparação de área plantada e produção entre Brasil e EUA (primeiro produtor mundial de soja e exemplo máximo de alta tecnologia e performance na sojicultura).

No ramo de fertilizantes, constata-se que os EUA já alcançaram o topo do rendimento médio possível para o cultivo de soja (HERINGER, 2017). Tal valor se estabelece em 3.230 toneladas por hectare, sendo quase 0 valor alcançado por alguns locais de cultivo de soja em Mato Grosso e Mato Grosso do Sul (gráfico 7). Tal valor de rendimento médio é superior à média brasileira (2.882 toneladas por hectare), ou seja, certas regiões sojícolas ainda têm muito o que expandir verticalmente em sua produção, tornando-se alvo prioritário de empresas regionais e transnacionais que lidam com insumos, especialmente sementes, fertilizantes e agrotóxicos ${ }^{15}$.

\footnotetext{
${ }^{15}$ Geralmente tais insumos são comercializados no esquema intitulado "venda casada". O produtor rural acaba adotando um pacote tecnológico de sementes, fertilizantes e agrotóxicos, geralmente controlado por empresas transnacionais.

Estudos Geográficos, Rio Claro, 15(1): 133-156, jan./jun. 2017 (ISSN 1678—698X)

http://www.periodicos.rc.biblioteca.unesp.br/index.php/estgeo
} 
Vulnerabilidade territorial e implicações sócio-espaciais...

Gráfico 6. EUA e Brasil. Comparação de área plantada e produção total de soja, safra $2015 / 2016$.

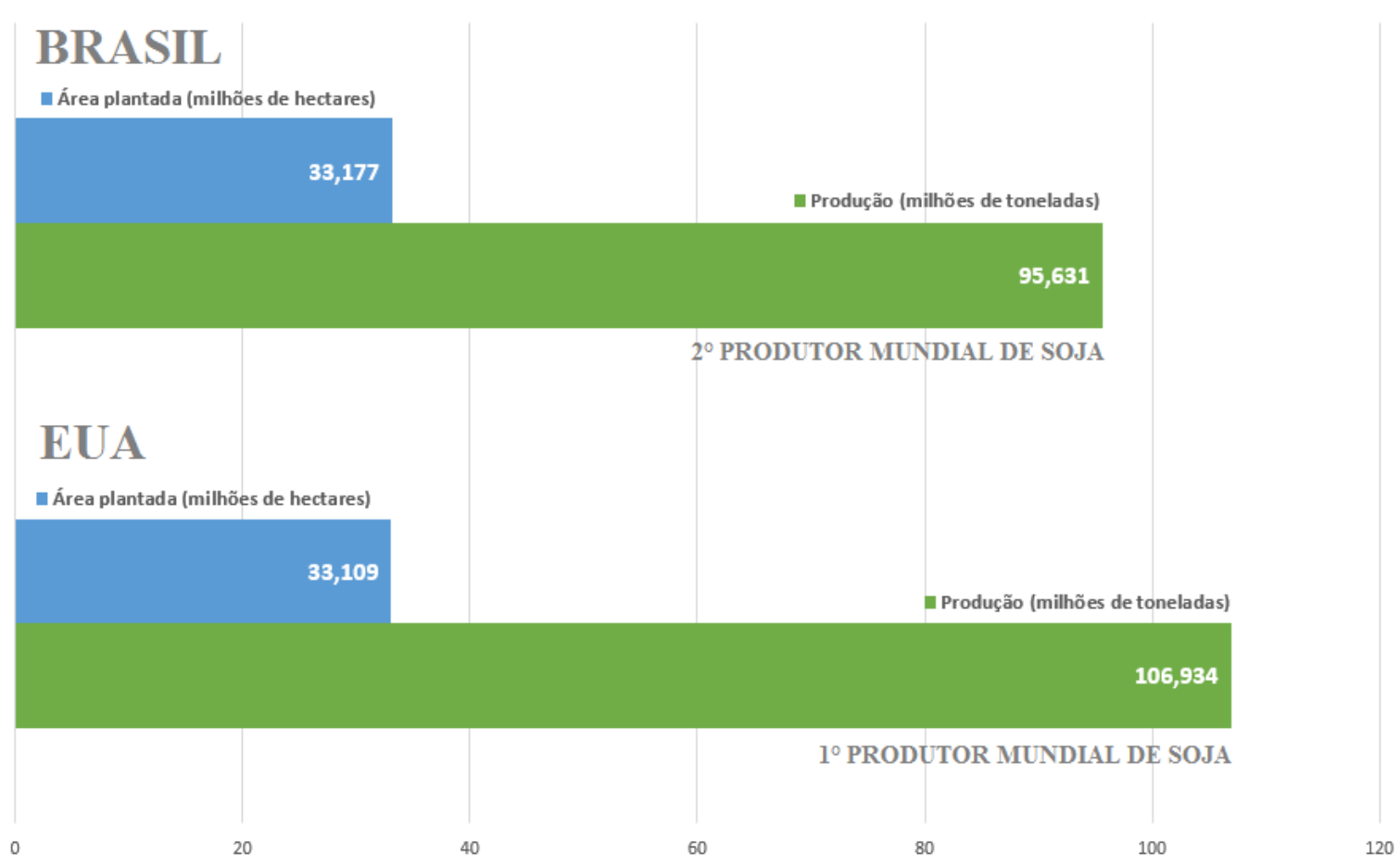

Fonte: USDA, CONAB, Embrapa Soja (2017).

Gráfico 7. Evolução do rendimento médio das lavouras de soja no Centro Oeste. Mato Grosso do Sul, Mato Grosso e Goiás, 1990, 1995, 2000, 2005, 2010 e 2015, em comparação com produtividade média, safra 2015/2016 de EUA e Brasil.

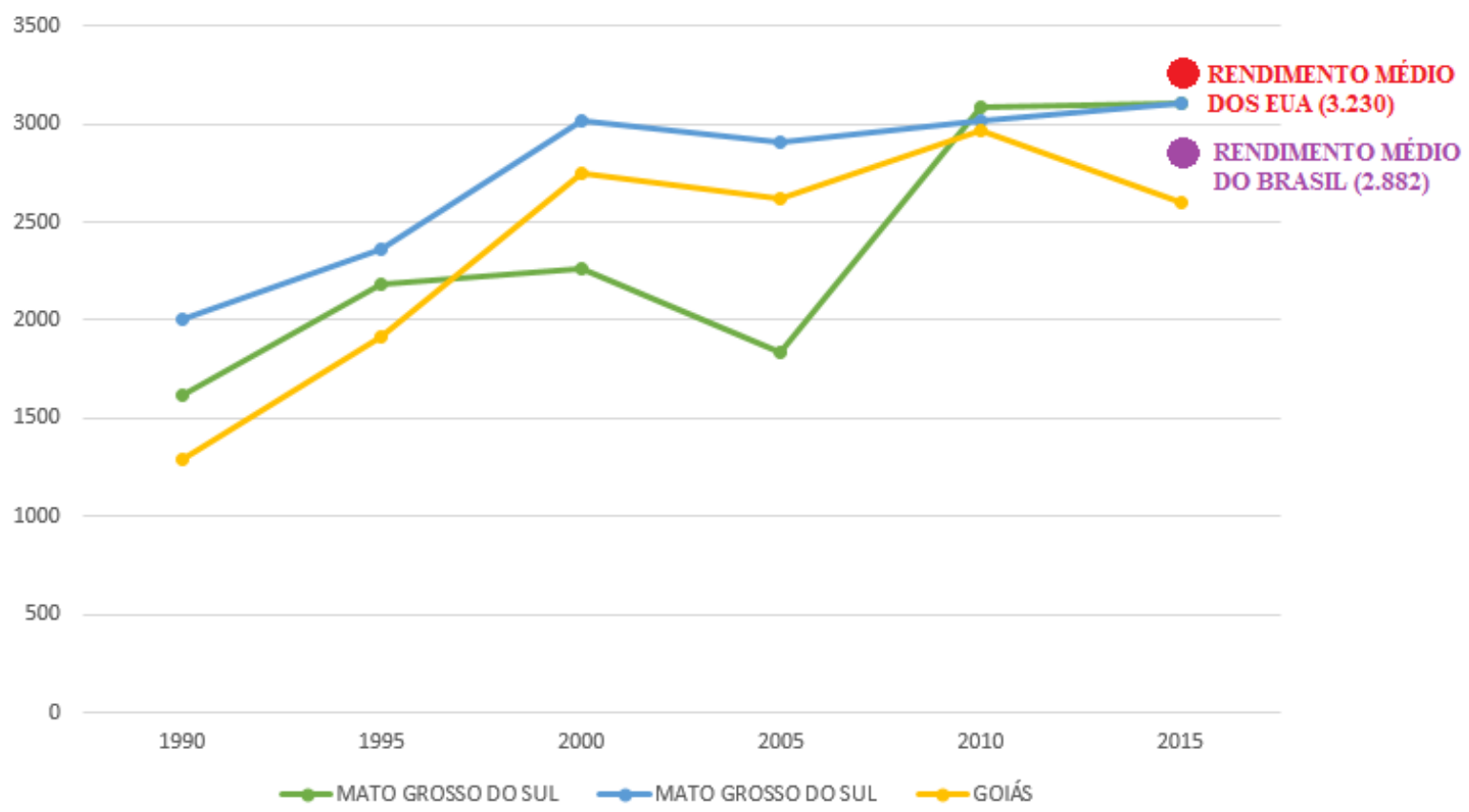

Fonte: USDA, CONAB, Produção agrícola municipal, IBGE (2017).

Estudos Geográficos, Rio Claro, 15(1): 133-156, jan./jun. 2017 (ISSN 1678-698X)

http://www.periodicos.rc.biblioteca.unesp.br/index.php/estgeo 
O estado de Mato Grosso do Sul apresenta regiões de expansão do cultivo intensivo de soja apontadas pelas associações setoriais (APROSOJA/FAMASUL). Conforme demonstrado pela figura 4, trata-se de áreas com predomínio de expansão horizontal da produção de soja; o aumento da quantidade produzida é baseado, quase que exclusivamente, na incorporação de novas áreas de plantio. Porém, no estado, notamos que há uma enorme capacidade de expansão vertical na produção de soja, uma vez que a lista dos atuais municípios com maior produção não é, necessariamente, a mesma lista dos municípios que apresentam maior rendimento médio em suas lavouras (figura 5). Tal fato indica que o uso intensivo de fertilizantes e agrotóxicos deve aumentar nos próximos anos nos municípios voltados à soja em Mato Grosso do Sul, ocasionando inúmeros problemas ambientais capazes de gerar impactos significativos na saúde humana.

Figura 4. Mato Grosso do Sul. Áreas de expansão do cultivo de soja, 2015.

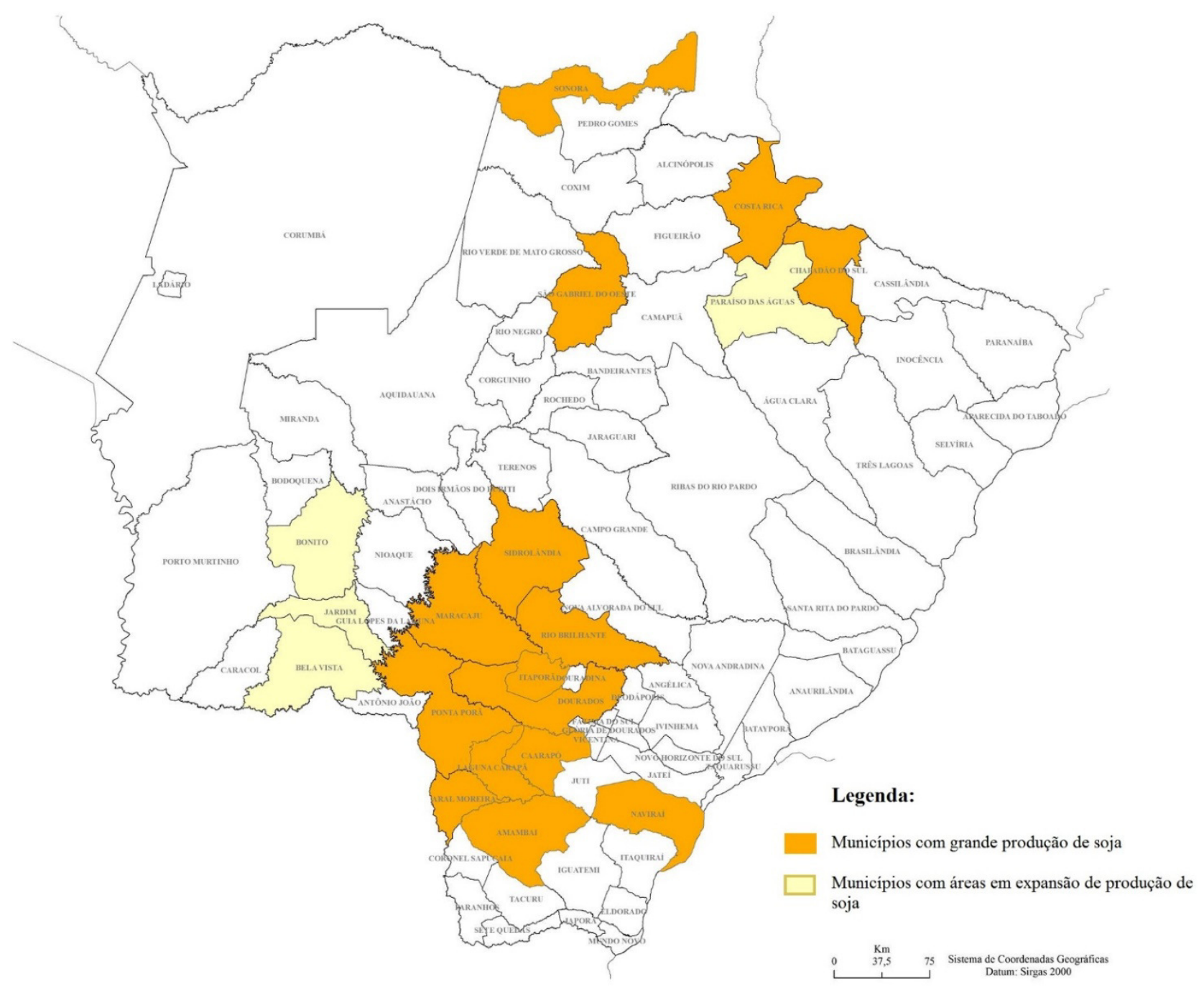

Fonte: Aprosoja (2015). Organizado pela autora. 
Figura 5. Mato Grosso do Sul. Municípios com maior quantidade produzida e maior rendimento médio da soja, 2015.

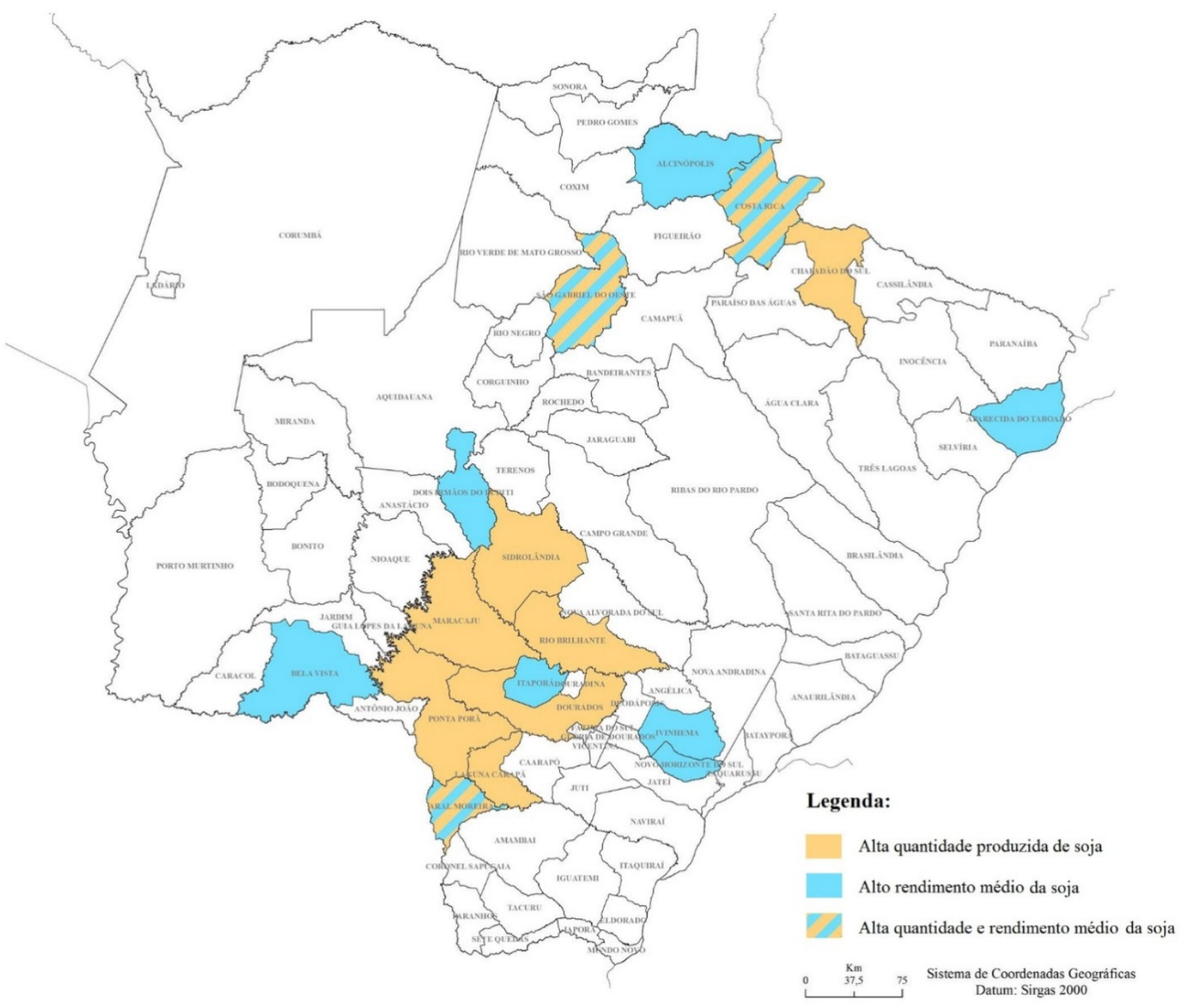

Fonte: Produção Agrícola Municipal/IBGE (2016). Organizado pela autora.

Efeitos imediatos do uso intensivo de agrotóxicos podem se revelar localmente, tais como contaminação de nascentes, córregos e rios, matando espécies vegetais e animais, além de insetos essenciais para a manutenção do equilíbrio biológico natural, como as abelhas e outros insetos importantes para a polinização de flores e frutos.

Segundo a EMBRAPA, os pequenos agricultores costumam ser muito mais vulneráveis e os maiores prejudicados pelo uso inadequado de agrotóxicos pois, na maioria das vezes, os utilizam de maneira indiscriminada e com pouca instrução (comumente no cultivo de hortaliças e frutas), aplicando mais do que a dose necessária e sem os devidos equipamentos de proteção, expondo o corpo ao veneno de maneira direta. A pressão econômica para não perder sua pequena produção, fonte principal de renda, aliado à falta de conhecimento técnico, também culmina do fato de que pequenos agricultores são os que menos seguem os critérios de devolução das embalagens: as acabam reutilizando, lavando, despejando a mistura de veneno e água no sistema de tratamento de esgoto dos municípios ou diretamente nos cursos d'água, por desconhecimento, falta de acesso às normas vigentes e, provavelmente, falta de orientação e fiscalização governamental. Desse

Estudos Geográficos, Rio Claro, 15(1): 133-156, jan./jun. 2017 (ISSN 1678-698X)

http://www.periodicos.rc.biblioteca.unesp.br/index.php/estgeo 
modo, às vezes, sem perceber, essa massa de trabalhadores fica totalmente exposta e vulnerável aos efeitos/sintomas agudos caudados pelos agrotóxicos (tabela 2).

Tabela 2. Classificação e efeitos e/ou sintomas agudos e crônicos dos agrotóxicos.

\begin{tabular}{|c|c|c|c|}
\hline $\begin{array}{l}\text { PRAGA QUE } \\
\text { CONTROLA }\end{array}$ & GRUPO QUIMICO & $\begin{array}{l}\text { SINTOMAS DE } \\
\text { INTOXICAÇAO } \\
\text { AGUDA }\end{array}$ & $\begin{array}{l}\text { SINTOMAS DE } \\
\text { INTOXICACCAO } \\
\text { CRONICA }\end{array}$ \\
\hline \multirow{3}{*}{ Inseticidas } & $\begin{array}{l}\text { Organofosforados } \\
\text { e carbamatos }\end{array}$ & $\begin{array}{l}\text { Fraqueza, cólicas } \\
\text { abdominais, vômitos, } \\
\text { espasmos musculares e } \\
\text { convulsões }\end{array}$ & $\begin{array}{l}\text { Efeitos neurotóxicos } \\
\text { retardados, alterações } \\
\text { cromossomiais e dermatites } \\
\text { de contato }\end{array}$ \\
\hline & Organoclorados & $\begin{array}{l}\text { Náuseas, vômitos, } \\
\text { contrações musculares } \\
\text { involuntárias }\end{array}$ & $\begin{array}{l}\text { Lesões hepáticas, arritmias } \\
\text { cardíacas, lesões renais e } \\
\text { neuropatias periféricas }\end{array}$ \\
\hline & $\begin{array}{l}\text { Piretroides } \\
\text { sintéticos }\end{array}$ & $\begin{array}{l}\text { Irritações das conjunti- } \\
\text { vas, espirros, excitação, } \\
\text { convulsões }\end{array}$ & $\begin{array}{l}\text { Alergias, asma brônquica, } \\
\text { irritações nas mucosas, hiper- } \\
\text { sensibilidade }\end{array}$ \\
\hline \multirow[t]{2}{*}{ Fungicidas } & Ditiocarbamatos & $\begin{array}{l}\text { Tonteiras, vômitos, } \\
\text { tremores musculares, dor } \\
\text { de cabeça }\end{array}$ & $\begin{array}{l}\text { Alergias respiratórias, derma- } \\
\text { tites, doença de Parkinson, } \\
\text { cânceres }\end{array}$ \\
\hline & Fentalamidas & - & Teratogêneses \\
\hline \multirow{3}{*}{ Herbicidas } & $\begin{array}{l}\text { Dinitroferóis e } \\
\text { pentaciclorofenol }\end{array}$ & $\begin{array}{l}\text { Dificuldade respiratória, } \\
\text { hipertermia, convulsões }\end{array}$ & $\begin{array}{l}\text { Cânceres (PCP-formação de } \\
\text { dioxinas), cloroacnes }\end{array}$ \\
\hline & Fenoxiacéticos & $\begin{array}{l}\text { Perda de apetite, enjoo, } \\
\text { vômitos, fasciculação } \\
\text { muscular }\end{array}$ & $\begin{array}{l}\text { Indução da produção de } \\
\text { enzimas hepáticas, cânceres, } \\
\text { teratogeneses }\end{array}$ \\
\hline & Dipiridilos & $\begin{array}{l}\text { Sangramento nasal, } \\
\text { fraqueza, desmaios, } \\
\text { conjuntivites }\end{array}$ & $\begin{array}{l}\text { Lesões hepáticas, dermatites } \\
\text { de contato, fibrose pulmonar }\end{array}$ \\
\hline
\end{tabular}

Fonte: OPAS/OMS (1996).

Fonte: Dossiê ABRASCO (2015, p. 59).

Situação inversa ocorre em relação aos grandes agricultores, grupo que utiliza os agrotóxicos de maneira massiva. Ao contrário dos pequenos, o uso é, de certa forma, controlado e feito de maneira terceirizada, o que os torna mais passíveis de fiscalização no que se refere à aplicação de veneno nas lavouras (seja essa via dispersão por terra ou através de aviação agrícola especializada). Os grandes produtores também são obrigados a obedecer às normas de descarte de embalagens em locais próprios, pois consomem esses tipos de insumo em grandes quantidades e as empresas acabam por oferecer esse tipo de recolhimento das embalagens (prática de logística reversa de embalagens de agrotóxicos, com postos de coletas específicos).

Estudos Geográficos, Rio Claro, 15(1): 133-156, jan./jun. 2017 (ISSN 1678—698X)

http://www.periodicos.rc.biblioteca.unesp.br/index.php/estgeo 
Mesmo que o uso de agrotóxicos pelos grandes agricultores seja, em tese, mais "controlado", são eles os responsáveis pelo uso massivo que acaba por dispersar grandes volumes de veneno nos cursos d'água e no ar, via dispersão aérea (muitas vezes em cima de aldeias e bairros rurais sul-mato-grossenses, localizados próximos às lavouras de soja). Nesse sentido, a população em geral também é afetada, embora não faça uso de tais substâncias de maneira ocupacional.

\begin{abstract}
O modelo de cultivo com o intensivo uso de agrotóxicos gera grandes malefícios, como poluição ambiental e intoxicação de trabalhadores e da população em geral. As intoxicações agudas por agrotóxicos são as mais conhecidas e afetam, principalmente, as pessoas expostas em seu ambiente de trabalho (exposição ocupacional). São caracterizadas por efeitos como irritação da pele e olhos, coceira, cólicas, vômitos, diarreias, espasmos, dificuldades respiratórias, convulsões e morte. Já as intoxicações crônicas podem afetar toda a população, pois são decorrentes da exposição múltipla aos agrotóxicos, isto é, da presença de resíduos de agrotóxicos em alimentos e no ambiente, geralmente em doses baixas. Os efeitos adversos decorrentes da exposição crônica aos agrotóxicos podem aparecer muito tempo após a exposição, dificultando a correlação com o agente. Dentre os efeitos associados à exposição crônica a ingredientes ativos de agrotóxicos podem ser citados infertilidade, impotência, abortos, malformações, neurotoxicidade, desregulação hormonal, efeitos sobre o sistema imunológico e câncer (INCA, 2015, p. 1).
\end{abstract}

Até esse ponto de nossa análise estávamos tratando de agrotóxicos liberados para venda em nosso território, sendo que há o grupo de agrotóxicos produzidos no Brasil e o grupo de produtos importados, em razão do consumo massivo dessas substâncias para a manutenção das lavouras de todo o País. Um grande problema enfrentado por estados que fazem fronteira com países vizinhos, como é o caso de Mato Grosso do Sul, é ter que lidar com o contrabando de agrotóxicos ilegais. Tais fluxos ilegais (de fertilizantes, agrotóxicos, mercadorias, aparatos tecnológicos importados, drogas, remédios e outras centenas de produtos) são incontroláveis e, por vezes, incomensuráveis. No que se refere aos agrotóxicos ilegais, a fronteira internacional, especialmente a seção sul-mato-grossense (fronteira seca), é um entreposto logístico importante na circulação nacional de agrotóxicos considerados ilegais no território brasileiro (fluxograma 1). 
Fluxograma 1. Representação da circulação global de agrotóxicos considerados ilegais no Brasil.

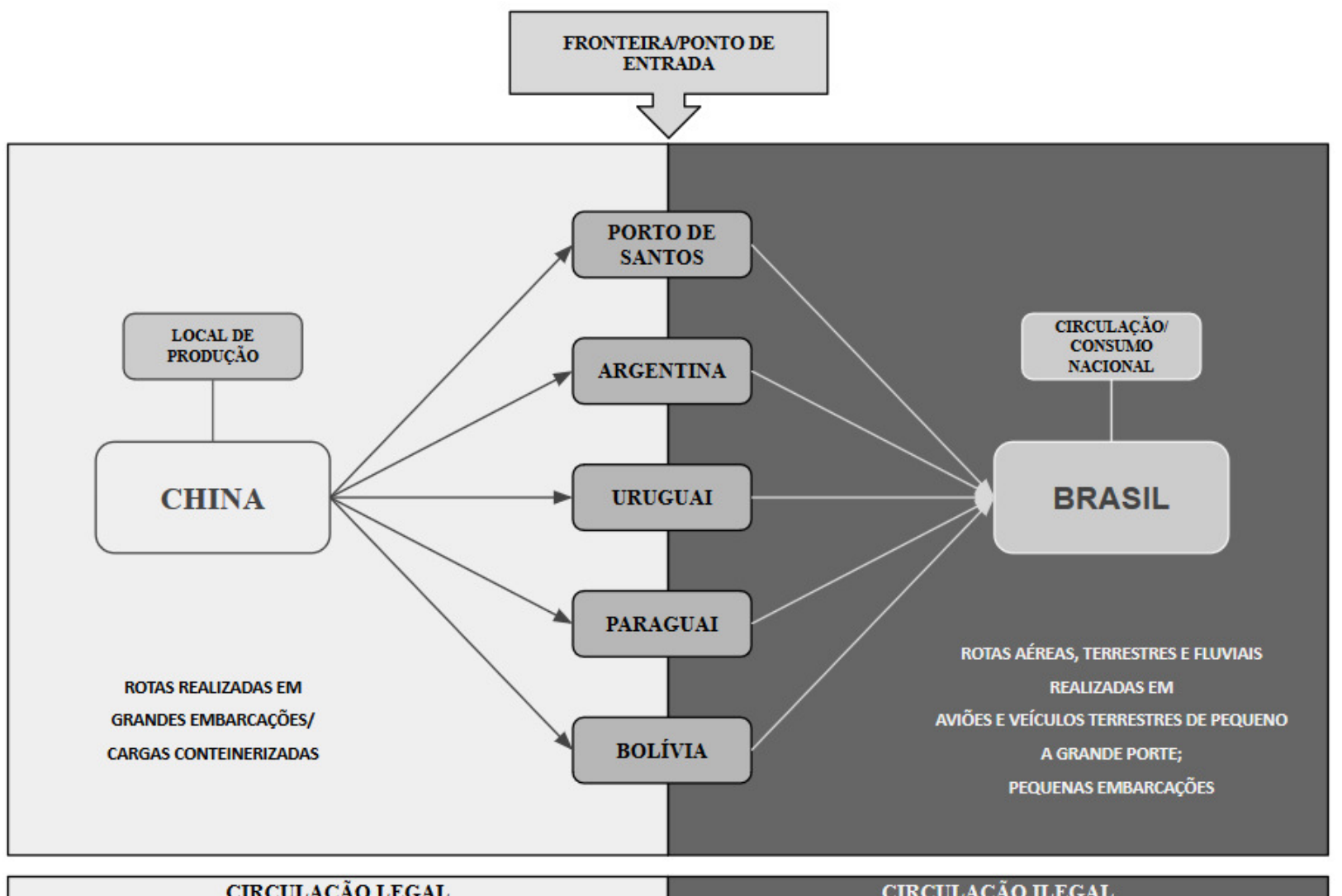

Fonte: SINDIVEG (2016). Organizado pela autora.

A maioria dos agrotóxicos considerados ilegais no Brasil (ou seja, não liberados pelo IBAMA e ANVISA) são fabricados na China, e seguem rotas em grandes embarcações até os principais portos dos países da América do Sul. Para entrarem no Brasil, os agrotóxicos ilegais geralmente seguem duas rotas distintas: a) pelo porto de Santos e b) pela fronteira internacional, notadamente via cidades gêmeas, especialmente as que apresentam fronteira seca, como o município de Ponta Porã, a 100 quilômetros do município de Dourados. Desse ponto em diante, o circuito é contrabando, sendo alvo de barreiras fiscais e policias a partir do momento em que circula em território sul-mato-grossense. A circulação de agrotóxicos ilegais segue um calendário próprio, com três períodos distintos (comércio, transporte e aplicação), que são organizados conforme o calendário de cultivo da cultura em que serão utilizados.

Atualmente, em nosso País, não existe outro modelo que possibilite a produção massiva de commodities que seja considerado viável para o agronegócio; o modelo que utiliza transgênicos e agrotóxicos (legais e ilegais) é, invariavelmente, dominante, o que culmina no não desenvolvimento de alternativas de cultivo, como a agroecologia, apoiada por órgãos como o INCA, por exemplo.

O modelo de produção vigente conta com todo o aparato político para se manter e se expandir, sendo apoiado pelo Estado, que deveria promover um uso mais democrático e sustentável, de fato, do território brasileiro. 
Em substituição ao modelo dominante, o INCA apoia a produção de base agroecológica em acordo com a Política Nacional de Agroecologia e Produção Orgânica. Este modelo otimiza a integração entre capacidade produtiva, uso e conservação da biodiversidade e dos demais recursos naturais essenciais à vida. Além de ser uma alternativa para a produção de alimentos livres de agrotóxicos, tem como base o equilíbrio ecológico, a eficiência econômica e a justiça social, fortalecendo agricultores e protegendo o meio ambiente e a sociedade (INCA, 2015, p. 5).

Desse modo, temos que a especialização produtiva pautada na sojicultura e observada fortemente na região de Dourados provoca algumas reflexões acerca da vulnerabilidade territorial a que esses municípios sul-mato-grossenses intimamente relacionados com a soja estão sujeitos, principalmente no que se refere à questão do emprego e arrendamento de pequenas propriedades rurais, convivência conflituosa com populações indígenas em busca da demarcações de suas terras e uso indiscriminado de agrotóxicos e outros insumos químicos, causadores de problemas de saúde, ocupacionais ou não, em regiões produtivas agrícolas.

\section{CONSIDERAÇÕES FINAIS}

Conforme nossa compreensão, o cultivo de commodities em larga escala nos países periféricos demanda alta eficiência, imperativo da busca por maior competitividade no período atual. Em nossa pesquisa, que tem foco nas regiões sojícolas sul-mato-grossenses, podemos determinar que 0 aumento da competitividade é diretamente proporcional ao aumento da vulnerabilidade, seja esta econômica, social ou ambiental. Nesse sentido, é objeto de preocupação e debate a vulnerabilidade territorial a que cidades fortemente envolvidas com a produção de monoculturas estão sujeitas. O caso sul-mato-grossense, em relação à soja, é desafiador, pois há no estado uma enorme população excluída dessa situação de pujança do agronegócio e seria papel fundamental do Estado (governo federal e estadual) promover e garantir igualdade de oportunidades para todos, articulando e regulando um uso mais democrático do território sul-mato-grossense.

\section{REFERÊNCIAS BIBLIOGRÁFICAS}

ALBRECHT, L. P.; MISSIO, R. F. Manejo de cultivos transgênicos. Palotina, PR: UFPR, 2013. $139 \mathrm{p}$.

APROSOJA-MS. Associação dos produtores de soja do Mato Grosso do Sul.

Disponível em: <http://www.aprosojams.org.br/notícias>. Acesso em: 01 julhos 2015.

BOMBARDI, L. M. Pequeno ensaio cartográfico sobre o uso de agrotóxicos no

Brasil. São Paulo: Laboratório de Geografia Agrária, Universidade de São Paulo; Blurb, 2016. 
BOMBARDI, L. Agrotóxicos, terra e dinheiro: a discussão que vem antes da prateleira. Entrevista concedida ao portal USP, Universidade de São Paulo. Disponível em: < http://www5.usp.br/107848/agrotoxicos-terra-e-dinheiro-a-discussao-que-vem-antesda-prateleira/>. Acesso em: 10 dev. 2016.

BRASIL. Ministério da Indústria, Comércio Exterior e Serviços. Comex vis: visualizações de comércio exterior. Disponível em:

$<\mathrm{http}$ ://www.mdic.gov.br/comercio-exterior/estatisticas-de-comercio-exterior/comexvis>. Acesso em: 10 jan. 2017.

CARNEIRO, F. F. (Org.). Dossiê ABRASCO: um alerta sobre os impactos dos agrotóxicos na saúde. Rio de Janeiro: EPSJV; São Paulo: Expressão Popular, 2015.

COMPANHIA NACIONAL DE ABASTECIMENTO, CONAB. Estoques públicos, séries históricas. Disponível em:

<http://www.conab.gov.br/conteudos.php?a=1111\&t=>. Acesso em: 02 nov. 2014.

ELIAS, D. O meio técnico-científico-informacional e a reorganização do espaço agrário nacional. In: MARAFON, G. J; RUA, J.; RIBEIRO, M. A. (Orgs.).

Abordagens teórico-metodológicas em geografia agrária. P. 49-66.1 ed. RJ: Ed UERJ, 2007.

EMBRAPA - EMPRESA BRASILEIRA DE PESQUISA AGROPECUÁRIA. Software Embrapa Soja. Disponível em: <https://www.embrapa.br/soja>. Acesso em: 10 fev. 2015.

GONÇALVES, J. S. Reprimarização ou Desindustrialização da Economia Brasileira: uma leitura a partir das exportações para o período 1997-2010. Análises e

Indicadores do Agronegócio. Instituto de Economia Agrícola, vol. 6, n. 12. São Paulo, dez. 2011.

INCA - INSTITUTO NACIONAL DE CÂNCER. POSICIONAMENTO DO INSTITUTO NACIONAL DE CÂNCER JOSÉ ALENCAR GOMES DA SILVA ACERCA DOS AGROTÓXICOS. Disponível em: < http://www1.inca.gov.br/inca/Arquivos/comunicacao/posicionamento_do_inca_sobre _os_agrotoxicos_06_abr_2015.pdf>. Publicado em: 6 abr. 2016. Acesso em: 01 nov. 2016.

MATTEI, L. Emprego agrícola: cenários e tendências. Estudos avançados, vol. 29, n॰85. São Paulo, set. / dez. 2015.

MISSIO, R. F.; GRANGE, L. Manejo de cultivos transgênicos: Melhoramento genético e a transgenia. Palotina, PR: UFPR, 2013. 7-24 p.

PETRINI, M. The use of analytic hierarchy process to priorize public policies for Family farming in na área of sugarcane expansion in the microregion of Ceres, 
Goiás. Tese (doutorado em Engenharia Agrícola). Universidade Estadual de Campinas. Campinas, 2016.

PEREIRA, M. F. KAHIL, S. P. A lógica corporativa do uso do território em Rondônia: o agronegócio da soja na região de Vilhena. CAMPO-TERRITÓRIO: revista de geografia agrária, v.5, n.10, p. 288-311, ago. 2010.

SANTOS, M. A natureza do espaço. Técnica e tempo, razão e emoção. São Paulo: Hucitec, 1996.

SINDIVEG - SINDICATO NACIONAL DA INDÚSTRIA DE PRODUTOS PARA A DEFESA VEGETAL. Apostila do curso "Combatendo agrotóxicos ilegais". Circulação restrita, 44 páginas, 2016. 